\title{
Preliminary Geologic Characterization of West Coast States for Geologic Sequestration
}

\author{
Topical Report \\ West Coast Regional Carbon Sequestration Partnership \\ (WESTCARB) \\ Contract Period: October 1, 2003-September 30, 2005
}

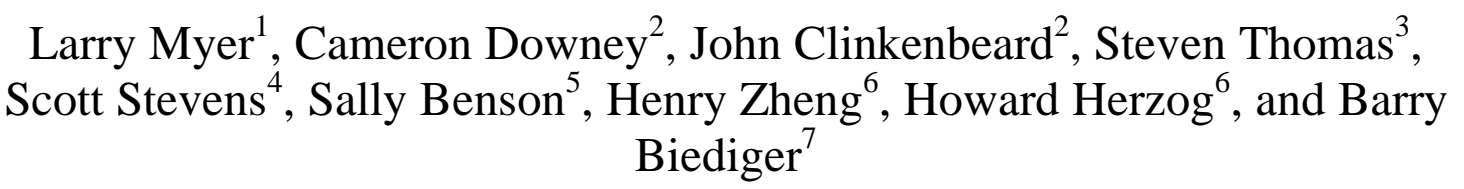

September 30, 2005

DOE Contract No.: DE-FC26-03NT41984

\author{
Submitted by: \\ Larry Myer \\ PIER Program \\ California Energy Commission \\ 1516 Ninth Street \\ Sacramento, CA 95814
}

${ }^{1}$ PIER Program, California Energy Commission, Sacramento, Calif.; ${ }^{2}$

California Geological Survey, Sacramento, Calif.; ${ }^{3}$ Golder Associates, Redmond, Wash.; ${ }^{4}$ Advanced Resources International, Inc. (ARI), Arlington, Virg.; ${ }^{5}$ Earth Sciences Division, Lawrence Berkeley National Laboratory, Berkeley, Calif.; ${ }^{6}$ MIT Lab for Energy and Environment, Cambridge, Mass.; Utah AGRC, Salt Lake City, Utah 


\section{United States Government Disclaimer}

This report was prepared as an account of work sponsored by an agency of the United States Government. Neither the United States Government nor any agency thereof, nor any of their employees, makes any warranty, express or implied, or assumes any legal liability or responsibility for the accuracy, completeness, or usefulness of any information, apparatus, product, or process disclosed, or represents that its use would not infringe privately owned rights. Reference herein to any specific commercial product, process, or service by trade name, trademark, manufacturer, or otherwise does not necessarily constitute or imply its endorsement, recommendation, or favoring by the United States Government or any agency thereof. The views and opinions of authors expressed herein do not necessarily state or reflect those of the United States Government or any agency thereof.

\section{California Energy Commission Disclaimer}

This report was prepared as a result of work sponsored by the California Energy Commission (Energy Commission). It does not necessarily present the views of the Energy Commission, its employees, or the State of California. The Energy Commission, the State of California, its employees, contractors, and subcontractors make no warranty, express or implied, and assume no legal liability for the information in this report; nor does any party represent that the use of this information will not infringe upon privately owned rights. This report has not been approved or disapproved by the Energy Commission, nor has the Energy Commission passed upon the accuracy or adequacy of this information in this report. 


\begin{abstract}
Characterization of geological sinks for sequestration of $\mathrm{CO}_{2}$ in California, Nevada, Oregon, and Washington was carried out as part of Phase I of the West Coast Regional Carbon Sequestration Partnership (WESTCARB) project. Results show that there are geologic storage opportunities in the region within each of the following major technology areas: saline formations, oil and gas reservoirs, and coal beds. The work focused on sedimentary basins as the initial most-promising targets for geologic sequestration. Geographical Information System (GIS) layers showing sedimentary basins and oil, gas, and coal fields in those basins were developed. The GIS layers were attributed with information on the subsurface, including sediment thickness, presence and depth of porous and permeable sandstones, and, where available, reservoir properties. California offers outstanding sequestration opportunities because of its large capacity and the potential of value-added benefits from enhanced oil recovery (EOR) and enhanced gas recovery (EGR). The estimate for storage capacity of saline formations in the ten largest basins in California ranges from about 150 to about $500 \mathrm{Gt}$ of $\mathrm{CO}_{2}$, depending on assumptions about the fraction of the formations used and the fraction of the pore volume filled with separate-phase $\mathrm{CO}_{2}$. Potential $\mathrm{CO}_{2}$-EOR storage was estimated to be $3.4 \mathrm{Gt}$, based on a screening of reservoirs using depth, an API gravity cutoff, and cumulative oil produced. The cumulative production from gas reservoirs (screened by depth) suggests a $\mathrm{CO}_{2}$ storage capacity of $1.7 \mathrm{Gt}$. In Oregon and Washington, sedimentary basins along the coast also offer sequestration opportunities. Of particular interest is the Puget Trough Basin, which contains up to $1,130 \mathrm{~m}(3,700 \mathrm{ft})$ of unconsolidated sediments overlying up to $3,050 \mathrm{~m}(10,000 \mathrm{ft})$ of Tertiary sedimentary rocks. The Puget Trough Basin also contains deep coal formations, which are sequestration targets and may have potential for enhanced coal bed methane recovery (ECBM).
\end{abstract}




\section{Table of Contents}

Abstract n...

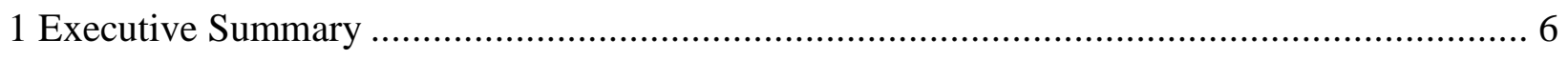

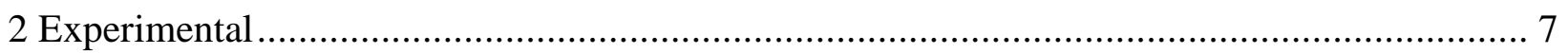

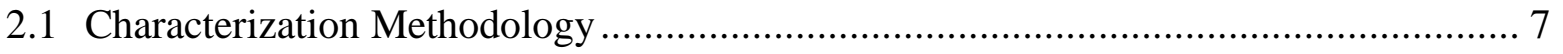

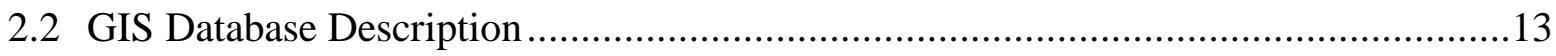

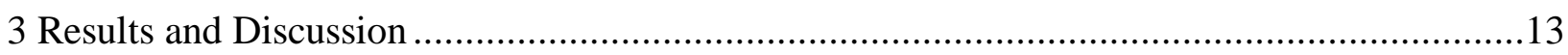

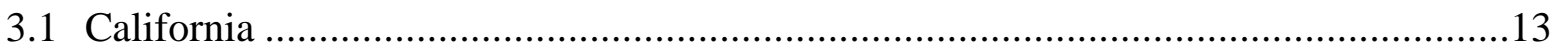

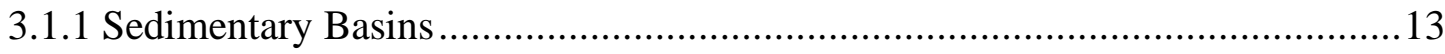

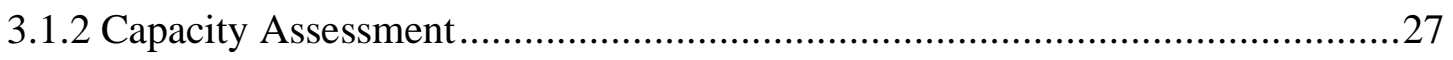

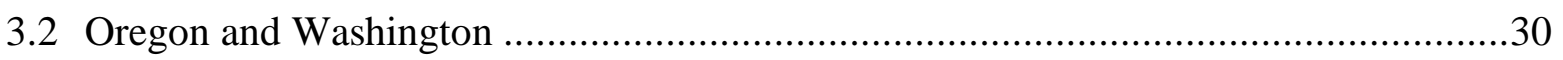

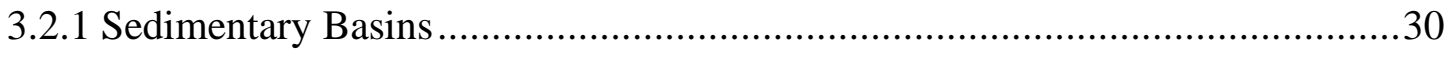

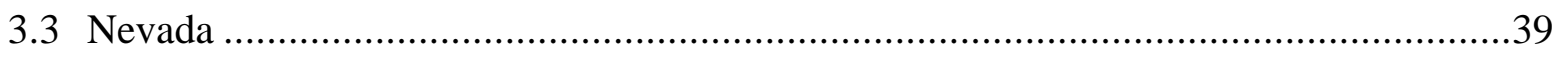

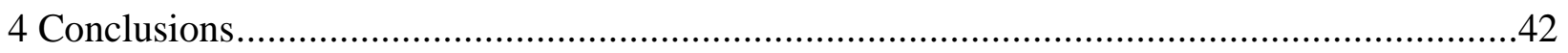

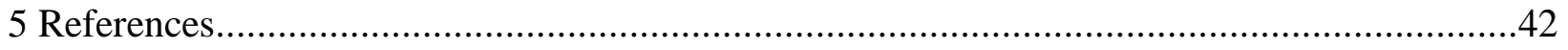

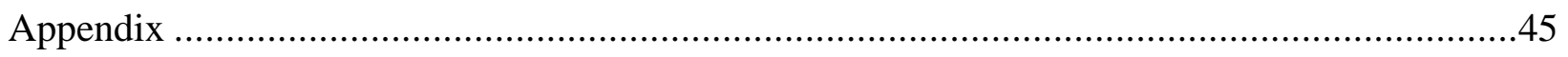

\section{List of Figures}

Figure 1. Generalized cross section through the southern Sacramento valley (adapted from DOG, 1983) ………………………….................................14

Figure 2. Generalized sandstone isopach map of the Sacramento Basin ....................................16

Figure 3. Generalized cross section through southern San Joaquin valley (adapted

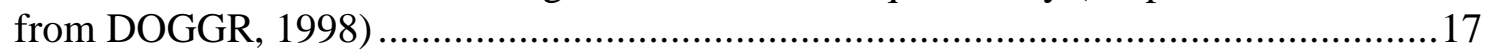

Figure 4. Generalized cross section through the Ventura Basin (adapted from

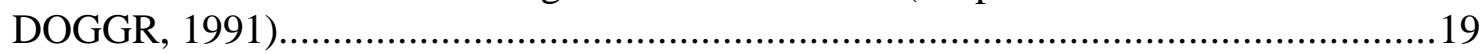

Figure 5. Generalized sandstone isopach map for the Ventura Basin........................................19

Figure 6. Generalized cross section through the Los Angeles Basin (adapted from

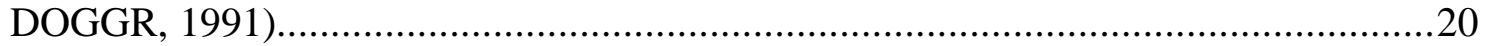

Figure 7. Generalized sandstone isopach map for the Los Angeles Basin..................................21

Figure 8. Generalized sandstone isopach map for the Eel River Basin ........................................22

Figure 9. Generalized sandstone isopach map for the Salinas and La Honda Basins...................24

Figure 10. Generalized sandstone isopach map for Cuyama Basin ...........................................25

Figure 11. Generalized sandstone isopach map for Livermore and Orinda Basins .....................27

Figure 12. Total sequestration capacity of saline formations in ten largest basins in

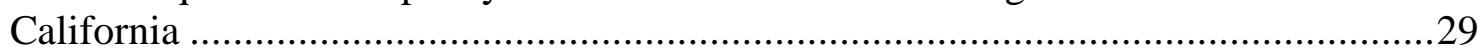

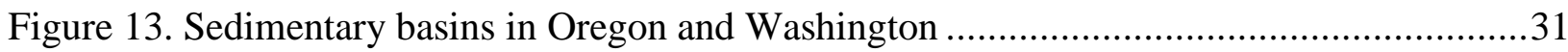

Figure 14. Sediment thickness in basins of Coastal Ranges of Washington..................................32

Figure 15. Sedimentary sub-basins in the Puget Trough of Washington.......................................34

Figure 16. Estimate of extent of coal basins in Puget Trough...................................................

Figure 17. Sedimentary basins and sediment thickness in the Oregon Coastal

Ranges. 
Figure 18. Nevada basins with fill thickness greater than one km (Price et al.,

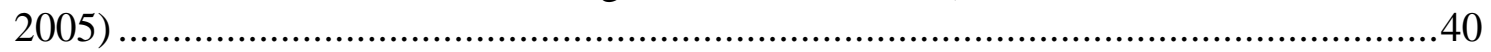

Figure 19. Conceptual model of oil reservoirs and saline formations in Nevada

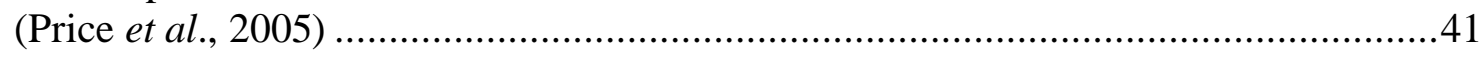

\section{List of Tables}

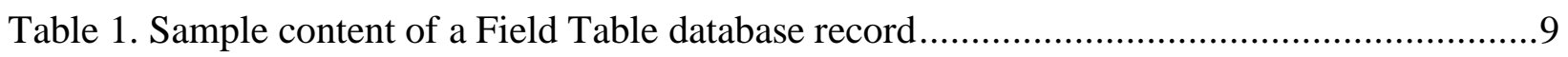

Table 2. Sample content of a Zone Table database record.........................................................10

Table 3. Information recorded from records of deep wells drilled in Nevada (Hess, $2004)$

Table 4. Data used for calculation of pore volume of California basins.....................................28 


\section{Executive Summary}

This report summarizes the characterization of regional geological sinks carried out as part of the Phase I WESTCARB project. This work includes a review of 104 sedimentary basins in California, an initial characterization of sedimentary basins and deep coal seams for sequestration in Washington and Oregon, assessments of oil and gas reservoirs in California, and assessment of sedimentary basins in Nevada.

The work focused on sedimentary basins as the initial most-promising targets for geologic sequestration. The approach for characterizing geological sinks in various states has followed similar steps: first, the extent (area) of the basins was determined and entered into a GIS layer. Baseline data were then collected and preliminary screening conducted, using such criteria as the presence of porous sediments, depth, and restricted access, resulting in a list of basins for which more detailed data on geologic properties were obtained. Priority was given to basins in which there are potential value-added benefits from enhanced oil recovery (EOR), enhanced gas recovery (EGR), and enhanced coal bed methane recovery (ECBM). Data from reservoirs in these basins form the bulk of the characterization data. The third step entailed evaluating CO2 storage capacity. Ultimately, the characterization data are integrated with source and transportation data to evaluate economics and develop supply curves for regional source/sink options.

In California, the screening process excluded basins from further consideration on the basis of lack of sufficient depth $(<800 \mathrm{~m}$, or $<2,625 \mathrm{ft})$, lack of porous or permeable rocks, or lack of identifiable seals. Basins underlying national parks and military installations were also excluded from further consideration. Of the 104 basins evaluated to date, 77 have been excluded for one of the reasons listed above. In conjunction with this effort, the California Geological Survey (CGS) prepared depth-to-basement and sandstone isopach maps of major sedimentary basins for which geophysical or well log data were available.

The oil and gas reservoirs in California were assessed by compiling and analyzing published state data, including discovery date and well, deepest well and depth, well locations, field area, cumulative production, base of freshwater, and specific physical rock and fluid properties for each producing, idle, or abandoned zone within each field. Results are being used to screen fields for $\mathrm{CO}_{2}$ storage potential and identify depleted or abandoned fields for $\mathrm{CO}_{2} \mathrm{EOR}$ or sequestration opportunities.

In Nevada, the minimum basin depth criterion was taken as $1,000 \mathrm{~m}(3,300 \mathrm{ft})$ due to a generally higher geothermal gradient in the Basin and Range province. An approach to account for the proximity of potential sinks to faults and mineral and geothermal resources was developed, and a conceptual model for saline formations and oil and gas reservoirs was created.

In Oregon and Washington, information on coal formations as potential sinks was compiled, as were data on the overall geology of sedimentary basins. For coal, available data on coal rank, percent methane saturation, and sorbtive capacity were compiled, in addition to other reservoir properties. 
Phase I work to date shows that excellent geologic storage opportunities exist in the WESTCARB region within each of the major technology areas: saline formations, oil and gas reservoirs, and coal beds.

California offers outstanding opportunities because of its large capacity and the potential of value-added benefits from EOR and EGR. Our estimate for the storage capacity of saline formations in the ten largest basins in California ranges from about 150 to about $500 \mathrm{Gt}$ of $\mathrm{CO}_{2}$, depending on assumptions about the fraction of the formations used and the fraction of the pore volume filled with separate-phase $\mathrm{CO}_{2}$. The low end of this range would provide sufficient capacity for storing over 1,000 years of utility and industrial sector emissions at the current emission rates.

The first sequestration targets are likely to be oil reservoirs where $\mathrm{CO}_{2} \mathrm{EOR}$ will help offset overall capture and storage costs. In California, most oil reservoirs are found in the San Joaquin Basin, Los Angeles Basin, and southern coastal basins. Estimates made by WESTCARB investigators yielded a potential $\mathrm{CO}_{2}$-EOR storage of $3.4 \mathrm{Gt}$, based on a screening of reservoirs using depth, an API gravity cutoff, and cumulative oil produced. Capacity estimates will be further refined in Phase II.

There are abundant gas reservoirs in the Sacramento Basin, including Rio Vista, the largest onshore gas field in California, which has produced over $9.3 \times 10^{10} \mathrm{~m}^{3}$ (3.3 Tcf) of natural gas since 1936. The cumulative production from gas reservoirs (screened by depth) in this basin suggests a $\mathrm{CO}_{2}$ storage capacity of $1.7 \mathrm{Gt}$.

In Oregon and Washington, sedimentary basins along the coast offer sequestration opportunities. Of particular interest is the Puget Trough Basin, which contains up to $1,130 \mathrm{~m}(3,700 \mathrm{ft})$ of unconsolidated sediments overlying up to $3,050 \mathrm{~m}(10,000 \mathrm{ft})$ of Tertiary sedimentary rocks. The Puget Trough Basin also contains deep coal formations, which are sequestration targets and may have potential for ECBM. The amount of unmineable coal in the Puget Sound basin was estimated to be over 70 billion tons, with a $\mathrm{CO}_{2}$ storage potential of $2.8 \mathrm{Gt}$.

In Nevada, many small basins were identified, but there is generally a paucity of information on the structure and properties of these sediments. Assessments of their suitability and of the potential for mineral storage techniques using mafic rock will be carried out in Phase II.

\section{Experimental}

\subsection{Characterization Methodology}

WESTCARB has focused on sedimentary basins as the initial most-promising targets for geologic sequestration. Our approach for various states has followed similar steps: First, the extent (area) of the basins is determined and entered into a GIS layer. Second, baseline data are collected and preliminary screening is conducted using such criteria as 
the presence of porous sediments, depth, and restricted access, resulting in a list of basins for which more detailed data on geologic properties are to be obtained. Priority is given to basins in which there are potential value-added benefits from enhanced oil recovery (EOR), enhanced gas recovery (EGR), and enhanced coal bed methane recovery (ECBM). Data from reservoirs in these basins form the bulk of the characterization data. The third step entails evaluating $\mathrm{CO}_{2}$ storage capacity. The final step integrates the characterization data with source and transportation data to evaluate economics and develop supply curves for regional source/sink options.

In California, the California Geologic Survey identified and catalogued sedimentary basins within California's 11 geomorphic provinces. Selected basins included all large or hydrocarbon-producing basins, as well as numerous smaller basins identified from the 1:750,000 scale geologic map of California (Jennings et al., 1977). Where basins extended offshore, only the onshore portions were considered. This resulted in an inventory of 104 basins, outlines of which were digitized to produce a California sedimentary basin GIS layer. This layer was combined with a California oil and gas field layer to illustrate the distribution of known oil and gas fields. Basins were screened to determine preliminary suitability for potential $\mathrm{CO}_{2}$ sequestration, with those basins not meeting the screening criteria excluded from further consideration. Screening involved literature searches and analysis of available well logs. Criteria included the presence of significant porous and permeable strata, thick and pervasive seals, and sufficient sediment thickness to provide critical state pressures for $\mathrm{CO}_{2}$ injection $(>800 \mathrm{~m}-2,625$ $\mathrm{ft}$ ). Accessibility was also considered, with basins overlain by national and state parks and monuments, wilderness areas, Bureau of Indian Affairs-administered lands, and military installations being excluded. Most of the basins excluded for this reason are located in the arid desert valleys of the Basin and Range and Mojave Desert geomorphic provinces. Structural closure or stratigraphic trapping was not considered a prerequisite for saline aquifers at the screening level.

To identify areas of adequate sedimentary fill, depth-to-basement contour maps were prepared for those basins containing sufficient basement penetrations. This included the Sacramento, San Joaquin, and Salinas basins. In some producing basins, where basement well control is limited or absent, basement contour maps were extrapolated from shallower structure maps (Eel River Basin), or published geophysical depth-to-basement maps were used (Los Angeles, Ventura Basins).

To characterize potential saline aquifers and hydrocarbon reservoirs, oil and gas field and reservoir data were assembled for depleted and producing fields. Data was compiled in field level and reservoir-level databases and attributed to the California oil and gas field GIS layer for manipulation and spatial analysis by other WESTCARB participants. Fieldlevel data included information such as location, depth, field area, cumulative production, and depth-to-base of fresh water. Field-level database parameters are shown in Table 1. 


\section{Table 1. Sample content of a Field Table database record}

\begin{tabular}{|ll|}
\hline \multicolumn{1}{|c|}{ Field Code: } & \multicolumn{1}{c|}{ VE024 } \\
Field: & Honor Rancho Oil \\
Discovery Well & The Texas Co. \\
Operator: & Honor Rancho A -1 \\
Discovery Well: & 6 \\
Section: & $4 \mathrm{~N}$ \\
Township: & $16 \mathrm{~W}$ \\
Range: & SB \\
Meridian: & $8 / 1 / 1950$ \\
Discovery Date: & So. California Gas Co. \\
Deepest Well Operator: & Wayside Unit 28 \\
Deepest Well: & 7 \\
Section: & $4 \mathrm{~N}$ \\
Township: & $16 \mathrm{~W}$ \\
Range: & SB \\
Meridian: & 11,747 \\
Depth (ft.) & 450 \\
Field Area (ac.) & 31,098 \\
Cum. Oil Prod. (MBO) & 52,992 \\
Cum. Gas Prod. & 1,150 \\
(MMCF) & \\
Base Fresh Water: & \\
\hline
\end{tabular}

Reservoir-specific parameters for producing, abandoned, or shut-in reservoirs in each field were compiled in the reservoir-level database. These data included reservoir fluid (oil, gas, water), zone status (producing, abandoned, shut-in), average depth, average thickness, producing area, porosity, permeability, initial pressure and temperature, formation water salinity, seal thickness, trap type (structural or stratigraphic), and history of secondary and tertiary recovery efforts. A measure of "fracture intensity" was assigned for most reservoirs to instill a general sense of fracturing and/or faulting. This subjective measure was assigned a value of low, medium, or high, based solely on the number of mapped faults illustrated in published California Department of Conservation, Division of Oil, Gas, and Geothermal Reservoirs (DOGGR) field maps ( $\mathrm{L}=0-1$ fault; $\mathrm{M}=2-3$ faults; $\mathrm{H}=4+$ faults). An example of reservoir database parameters is shown in Table 2 . 
Table 2. Sample content of a Zone Table database record

\begin{tabular}{|c|c|c|c|}
\hline Field Code: & VE024 & Perm. (md): & 20 \\
\hline Zone: & Modelo Fm. & Perm. Range Min. (md): & 179 \\
\hline Age: & U. Miocene & Perm. Range Max. (md): & \\
\hline Oil or Gas: & $\mathrm{O}$ & Pressure (lb/ft.): & 2,962 \\
\hline Date of Discovery: & $12 / 1 / 1950$ & Press. Range Min. (lb/ft.): & 4,500 \\
\hline Zone Status (P/A/SI): & $\mathrm{P}$ & Press. Range Min. (lb/ft.): & 190 \\
\hline API Gravity: & & Temperature $\left({ }^{\circ} \mathrm{F}\right)$ : & \\
\hline API Range Min.: & 35 & Temp. Range Min. $\left({ }^{\circ} \mathrm{F}\right)$ : & \\
\hline API Range Max.: & 39 & Temp. Range Max. $\left({ }^{\circ} \mathrm{F}\right)$ : & \\
\hline GOR: & & Salinity (ppm NaCl): & \\
\hline GOR Range Min.: & 220 & $\begin{array}{l}\text { Sal. Range Min. (ppm } \\
\mathrm{NaCl} \text { ): }\end{array}$ & 11,200 \\
\hline GOR Range Max.: & 1,250 & $\begin{array}{l}\text { Sal. Range Max. (ppm } \\
\mathrm{NaCl} \text { ): }\end{array}$ & 24,800 \\
\hline Sp. Gravity: & & TDS (ppm): & 20,200 \\
\hline Sp. Gravity Min.: & 0.470 & TDS Range Min. (ppm): & \\
\hline Sp. Gravity Max.: & 0.765 & TDS Range Max. (ppm): & \\
\hline BTU: & 1,066 & Seal: & Modelo Fm. \\
\hline BTU Range Min.: & & Seal Thickness (ft.): & \\
\hline BTU Range Max.: & & Seal Thickness Min. (ft.): & 5 \\
\hline Cum. Oil (MBO): & 29,094 & Seal Thickness Max. (ft.): & 50 \\
\hline Cum. Gas (MMCF): & 47,601 & Trap Type: & Stratigraphic \\
\hline No Pool Breakdown: & & Fault Intensity: & $\mathrm{L}$ \\
\hline Depth (ft.): & & ERP 1: & Gas Injection \\
\hline Depth Range Min.: & 6,481 & ERP 1 Start: & 1954 \\
\hline Depth Range Max.: & 10,000 & ERP 1 Stop: & 1956 \\
\hline Thickness (ft.): & & ERP 2: & Waterflood \\
\hline Thickness Range Min. (ft.): & 94 & ERP 2 Start: & 1959 \\
\hline Thickness Range Max. (ft.): & 310 & ERP 2 Stop: & 1966 \\
\hline Producing Area (ac.): & 400 & ERP 3: & Waterflood \\
\hline Porosity (\%): & & ERP 3 Start: & 1972 \\
\hline Porosity Range Min. (\%): & 7 & ERP 3 Stop: & 1975 \\
\hline Porosity Range Max. (\%): & 26 & & \\
\hline
\end{tabular}

In Nevada, the minimum-basin-depth criterion was taken as $1,000 \mathrm{~m}(3,300 \mathrm{ft})$, owing to a generally higher geothermal gradient in the Basin and Range province. The Nevada 
Bureau of Mines and Geology (NBMG) developed a GIS-based screening methodology that takes into account the proximity of potential geologic sinks to faults, mineral and geothermal resources, populated areas, other restricted lands, and water resources (Price et al., 2005). The NBMG also developed a method, illustrated in Table 3, to interrogate well records for information relevant to geologic sequestration. 
Table 3. Information recorded from records of deep wells drilled in Nevada (Hess, 2004)

\section{DEFINITIONS}

$\mathrm{CO}_{2}$ reservoir rock $\equiv$ sandstone, conglomerate, sand, or gravel

Seal rock $\equiv$ shale, mudstone, claystone, mud, clay, halite, gypsum, salt, or nonwelded (possibly clay- or zeolite-altered) ash-flow tuff

\section{NEITHER A $\mathrm{CO}_{2}$ RESERVOIR ROCK NOR SEAL $\equiv$} limestone, dolomite, fractured volcanic rock, fractured sandstone, quartzite, metamorphic rocks, or granite or other igneous rocks

Data collected from well records, if available, in wells within areas not otherwise excluded for consideration of $\mathrm{CO}_{2}$

1. Total depth of well.

2. Are there potential $\mathrm{CO}_{2}$ reservoir rocks in the well below $1 \mathrm{~km}(3,281 \mathrm{ft})$ depth? If no, go to next well.

3. Is there a potential seal below $1 \mathrm{~km}$ and above that reservoir rock? If no, go to next well.

4. Depth to base of Cenozoic/Tertiary volcanic rocks and alluvium.

5 . Depth to base of deepest reservoir rock in pre-Tertiary sedimentary package.

6. How fresh is the water in this deepest reservoir rock? (Total dissolved solids - TDS?)

7. How porous is this deepest reservoir rock? \% of porosity?

8. How permeable is this deepest reservoir rock? $\mathrm{K}$ in millidarcy?

9. Thickness of the thickest single pre-Tertiary reservoir rock.

10. How fresh is the water in this thickest pre-Tertiary reservoir rock?

11. How porous is this thickest pre-Tertiary reservoir rock?

12. How permeable is this thickest pre-Tertiary reservoir rock?

13. Total thickness of all pre-Tertiary reservoir rocks.

14. Thickness of the thickest single pre-Tertiary seal rock above the deepest reservoir rocks.

15. Total thickness of all pre-Tertiary seal rocks above the deepest reservoir rocks.

16. Depth to base of deepest reservoir rock in Tertiary sedimentary package below $1 \mathrm{~km}$.

17. How fresh is the water in this deepest reservoir rock in Tertiary package?

18. How porous is this deepest reservoir rock in Tertiary package?

19. How permeable is this deepest reservoir rock in Tertiary package?

20. Thickness of the thickest single Tertiary reservoir rock below $1 \mathrm{~km}$.

21. How fresh is the water in this thickest single Tertiary reservoir?

22. How porous is this thickest single Tertiary reservoir?

23. How permeable is this thickest single Tertiary reservoir?

24. Total thickness of all Tertiary reservoir rocks below $1 \mathrm{~km}$.

25. Thickness of thickest single Tertiary seal rock below $1 \mathrm{~km}$.

26. Total thickness of all Tertiary seal rocks below $1 \mathrm{~km}$.

27. Total thickness of all Tertiary seal rocks below $1 \mathrm{~km}$ and above shallowest reservoir rock.

28. Thickness of halite beds below $1 \mathrm{~km}$.

FACTORS THAT CAN NOW BE DERIVED FROM THESE NUMBERS

A. Total thickness of potential reservoir rocks $=\# 13+\# 24$

B. Total thickness of potential seal rocks above the deepest reservoir rock and below $1 \mathrm{~km}=$ $\# 15+\# 26$

C. Reservoir rock to seal rock ratio $=\# \mathrm{~A} / \# \mathrm{~B}, \sim$ sand $/$ shale ratio 
In Oregon and Washington, GIS layers were developed that give the location of sedimentary basins. Data on the overall geology of sedimentary basins and the available reservoir properties were assembled. Data from the few available deep wells penetrating the basalt layers in the eastern portions of the states were reviewed to establish the presence of sediments at depths $300 \mathrm{~m}(1,000 \mathrm{ft})$ to over 2,700 $\mathrm{m}(9,000 \mathrm{ft})$. Information on coal formations as potential sinks was also compiled, including available data on coal rank, percent methane saturation, and sorbtive capacity.

\subsection{GIS Database Description}

The GIS database for WESTCARB is housed in an Enterprise Geodatabase format using ArcSDE (Spatial Database Engine) from Environmental Systems Research Institute, Inc. (ESRI). This database can be connected directly to any ESRI ArcMap client version 9.0 or greater. The data layers can also be requested from AGRC in a format that can be used in any common GIS software. A complete list of available layers is given in Appendix I. The layers are organized into the main categories of "sedimentary basins," "sources," and "base layers." The sedimentary basin category contains sub-categories of "geologic features" and "supporting data".

An interactive web map has been created to provide access to the data layers via the internet. This interactive map can be viewed at http://atlas.utah.gov/co2wc. In addition to providing a means by which the GIS data layers can be viewed and queried, this interactive map includes tools that let the user perform some basic analysis operations, such as buffering and linear distance measurement.

In addition to the compilation of the partnership database, the Utah Automated Geographic Reference Center (AGRC) has cooperated with, and will continue to cooperate with the NATCARB (national carbon) database in the modeling and serving of the nationwide distributed carbon atlas. The data layers are served via ESRI's ArcIMS map services, which are harvested by the NATCARB interactive map portal.

\section{Results and Discussion}

\subsection{California}

\subsubsection{Sedimentary Basins}

Of the 27 basins which met the screening criteria, the most promising are the larger Cenozoic marine basins, including the San Joaquin, Sacramento, Los Angeles, Ventura, and Salinas basins, followed by the smaller Eel River, La Honda, Cuyama, Livermore, and Orinda marine basins. Favorable attributes of these basins include (1) geographic diversity; (2) thick sedimentary fill with multiple porous and permeable aquifers and hydrocarbon reservoirs; (3) thick, laterally persistent marine shale seals; (4) locally abundant geological, petrophysical, and fluid data from oil and gas operations; and (5) numerous abandoned or mature oil and gas fields that might be reactivated for $\mathrm{CO}_{2}$ 
sequestration or benefit from $\mathrm{CO}_{2}$ enhanced recovery operations. Results for the above basins are summarized in the following pages. More detailed discussion of these, as well as other California sedimentary basins, is found in Downey and Clinkenbeard, 2005.

The Great Valley province is an elongated topographic valley approximately $725 \mathrm{~km}$ (450 miles) long lying between the Sierra Nevada and the Coast Ranges, and extending from the Klamath Mountains in the north to the Transverse Ranges in the south. The Great Valley consists of a large depositional basin that has received sediments almost continuously since the late Jurassic and contains, by some estimates, as much as 12,200 $\mathrm{m}(40,000 \mathrm{ft})$ of mostly marine, sedimentary rocks (Magoon and Valin, 1995). In the subsurface, the Great Valley is divided into the Sacramento Basin in the north and the San Joaquin Basin to the south, the point of division being the buried Stockton Arch south of the City of Stockton.

The Sacramento Basin is approximately $390 \mathrm{~km}$ (240 miles) long and averages about 80 $\mathrm{km}$ (50 miles) wide. In its current form, the basin comprises an asymmetric trough with a westerly dipping basement surface ranging from surface exposures in the Sierra foothills to depths estimated to be greater than 6,700 m (22,000 ft). In contrast to the oil-prone San Joaquin Basin, the Sacramento Basin is a natural gas-producing basin. Figure 1 is a generalized cross section from the southern portion of the basin, showing major sandstone units which constitute sequestration targets and shale units which represent regional seals. Formations containing important gas reservoirs include the Winters, Starkey, Mokelumne River, and Domengene. Porosities range from 15 to 35\%, and permeabilities range from $9.9 \times 10^{-15}$ to $1.7 \times 10^{-12} \mathrm{~m}^{2}$ (10 to $1,700 \mathrm{md}$; DOG, 1983).

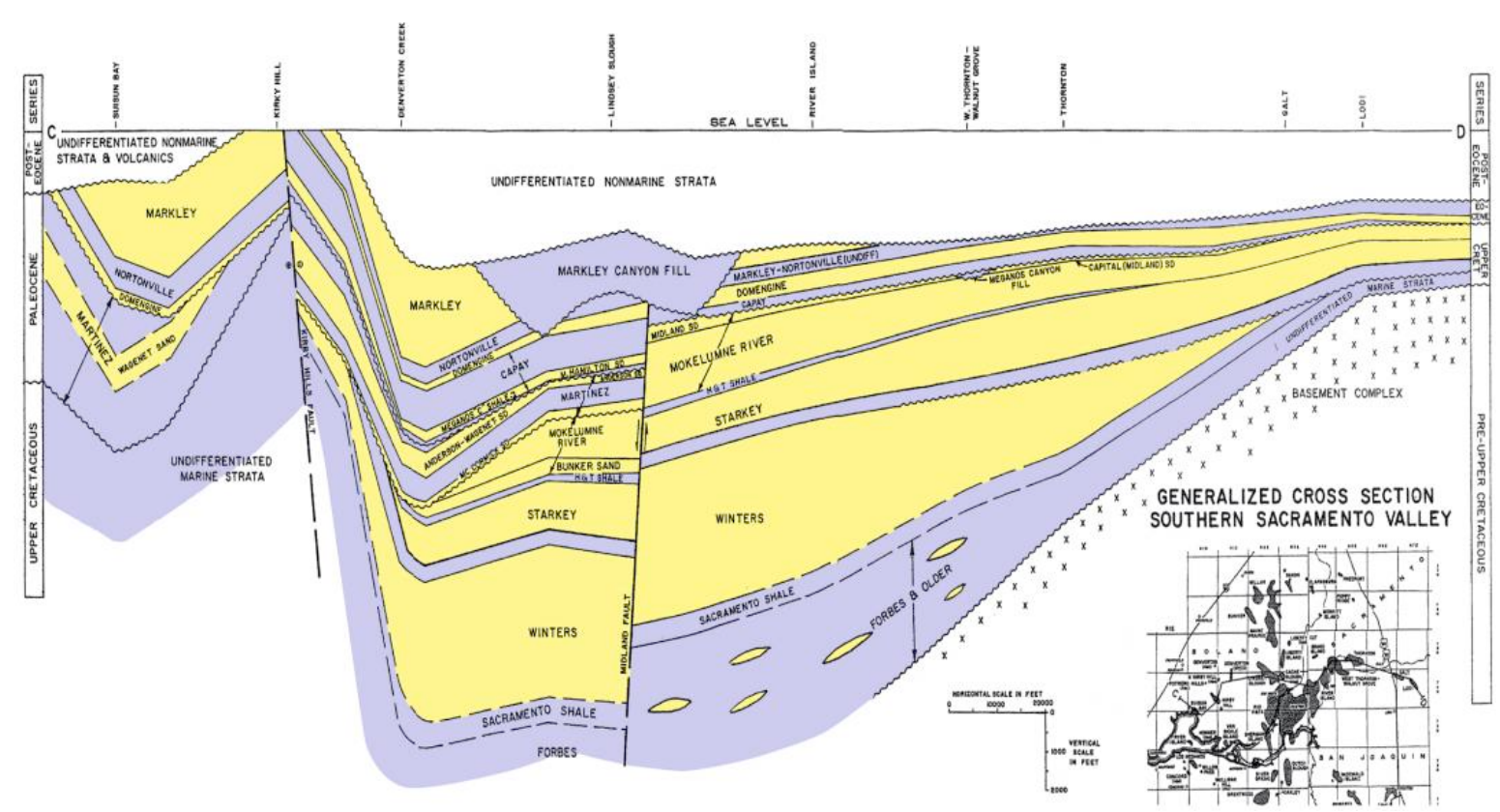

Figure 1. Generalized cross section through the southern Sacramento valley (adapted from DOG, 1983) 
A generalized sandstone isopach map of the Sacramento Basin (Figure 2) reveals good sandstone development paralleling the strike of the basin and ranging from over $300 \mathrm{~m}$ $(1,000 \mathrm{ft})$ in Tehama County to nearly $1,220 \mathrm{~m}(4,000 \mathrm{ft})$ in Stanislaus County. The southward thickening is largely the result of the post-Cretaceous regional unconformity, which progressively truncates the sand-rich Great Valley Sequence formations to the north, leaving only Forbes and Kione formation sandstones remaining in the northernmost counties. 


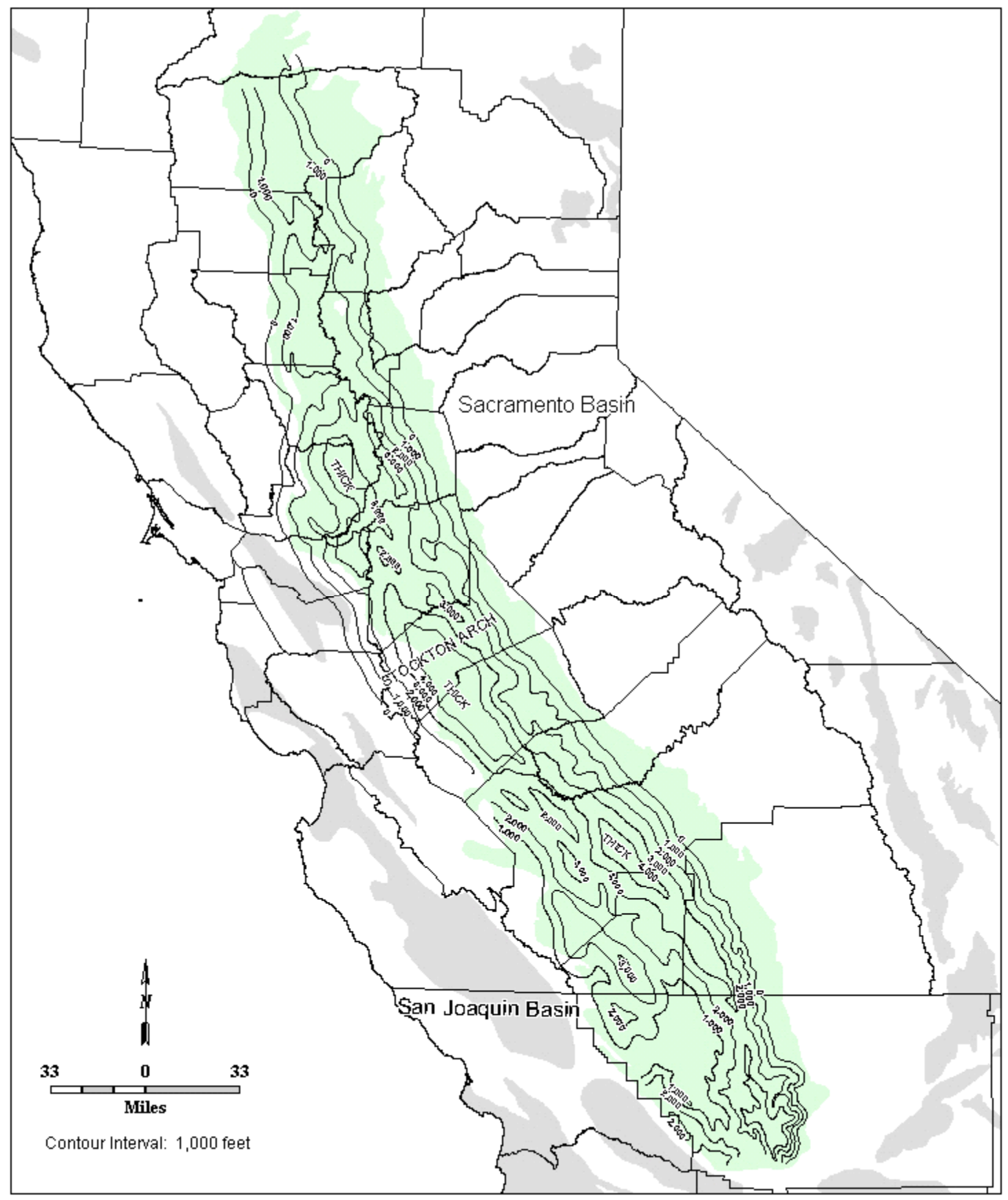

Figure 2. Generalized sandstone isopach map of the Sacramento Basin

The San Joaquin Basin comprises the southern half of the Great Valley province. It extends about $350 \mathrm{~km}$ (220 miles) from the Stockton Arch to its southern terminus at the northern Transverse Ranges and averages 80-115 m (50-70 miles) wide. It is bounded on the east by the Sierra Nevada and on the west by the Central Coast Ranges and the San Andreas Fault. 
The basin is filled with predominantly marine Cretaceous and Cenozoic clastic sedimentary rocks that attain an aggregate thickness of over 9,150 m (30,000 ft). A generalized cross section in Figure 3 shows sandstone formations that are sequestration targets, and regional shale seals. Important oil producing formations include the Gatchell, Vedder, Jewett, and Pyramid Hill, Temblor, Stevens, Chanac and Santa Margarita, and Etchegoin. Porosities range from $10-40 \%$ and permeabilities from $2.0 \times 10^{-16}$ to $9.9 \times 10^{-12}$ $\mathrm{m}^{2}(0.2 \mathrm{md}$ to $10,000 \mathrm{md})$. Porosity and permeability decrease with depth (DOGGR, 1998).

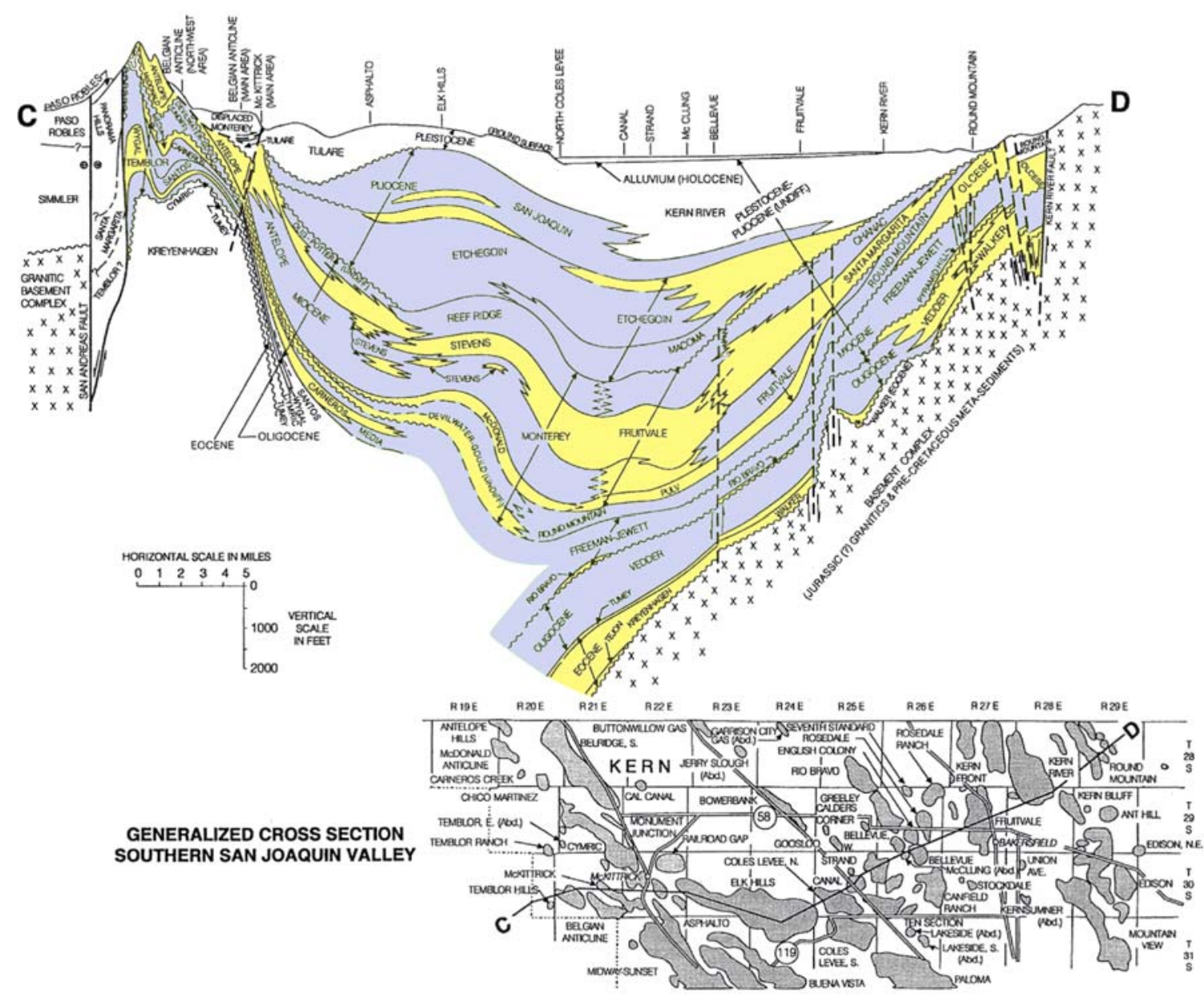

Figure 3. Generalized cross section through southern San Joaquin valley (adapted from DOGGR, 1998)

A gross sandstone isopach map (Figure 2) shows that sandstone occurs in a trend thickening to over $1,220 \mathrm{~m}(4,000 \mathrm{ft})$ parallel to the basin axis. Unlike the Sacramento Basin, the isopach interval includes largely Eocene Gatchell Formation through Pliocene San Joaquin Formation sandstones deposited above the post-Cretaceous unconformity. However, some upper Cretaceous Great Valley Sequence sandstones contribute to the isopach in the northern basin, while lower beds of the Kern River and Tulare formations 
are included in deeper portion of the southern basin.

The Transverse Ranges are an east-west trending series of mountain ranges and valleys extending about $515 \mathrm{~km}$ (320 miles) from Point Arguello eastward to the Mojave Desert. The largest and most important sedimentary basin within these ranges is the Ventura Basin, a complexly folded and faulted Cenozoic marine sedimentary basin. The western two thirds of the basin extends offshore to include the Santa Barbara Channel between the Channel Islands and Santa Ynez Mountains. The onshore portion comprises about $4,079 \mathrm{~km}^{2}$ (1,575 square miles), including the Santa Clara Valley and Oxnard Plain. The onshore basin is bounded by the Santa Ynez and Santa Monica mountains to the north and south, respectively, and the San Gabriel Fault to the east. The Ventura Basin is the deepest of California's Cenozoic basins, containing more than 17,700 m (58,000 ft) of largely marine sediments. Consequently, the basin includes numerous upper Cretaceous through Pleistocene-age sandstones with sequestration potential, and possibly EOR opportunities. Figure 4 is a generalized cross section of Ventura Basin, which is characterized by major east-west trending thrust faults and tightly folded anticlinal trends that contain the majority of the basin's oil reserves. The Modelo and Pico sandstones are major oil-producing formations with porosities varying from 15 to $35 \%$ and permeabilities ranging from $7.9 \times 10^{-15}$ to $5.9 \times 10^{-12} \mathrm{~m}^{2}$ (8 md to $6,000 \mathrm{md}$; DOGGR, 1991). Porosity and permeability decreases with depth. 


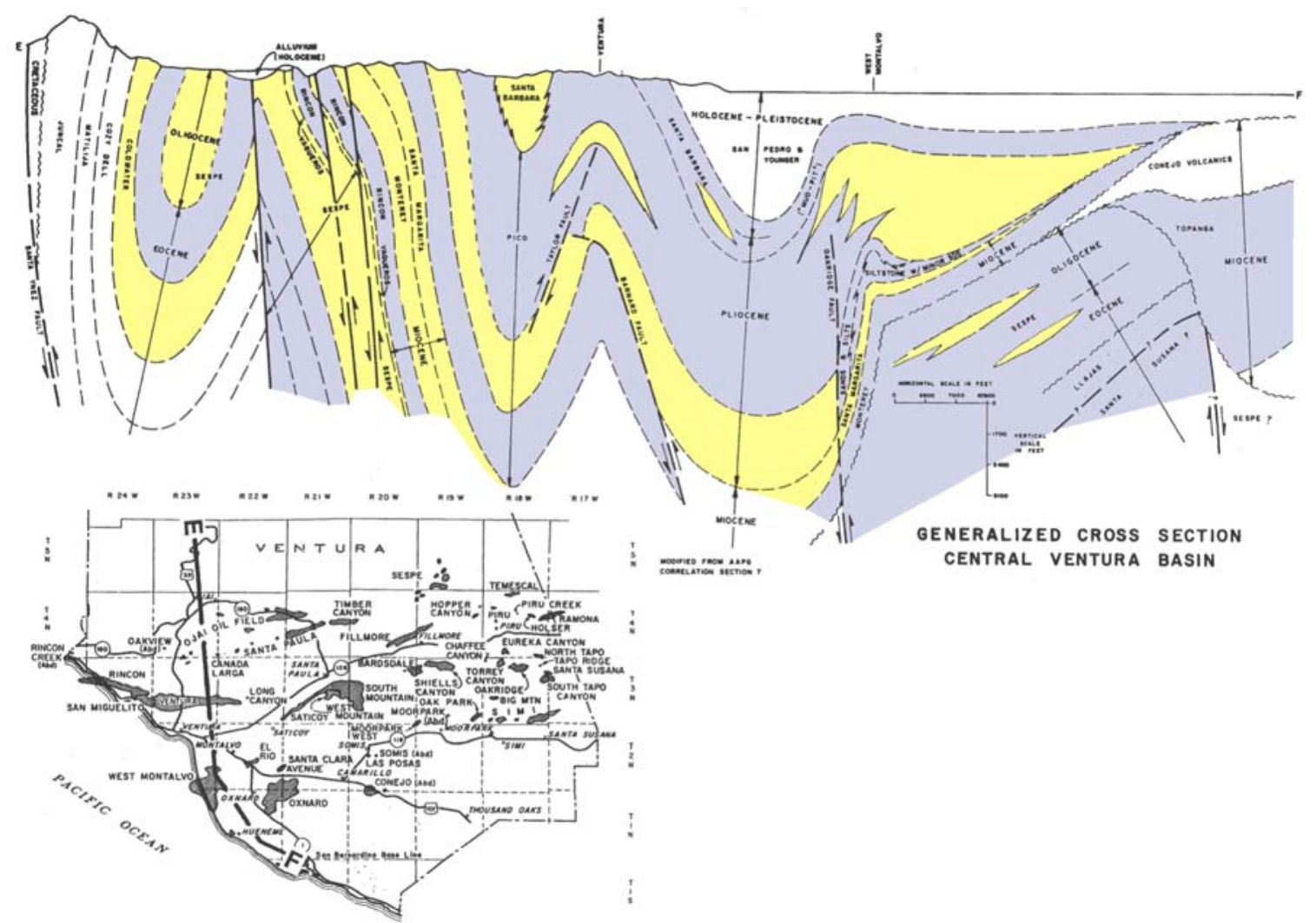

Figure 4. Generalized cross section through the Ventura Basin (adapted from DOGGR, 1991)

A sandstone isopach map for the Ventura Basin reveals three thick east-west trending sandstone zones, each exceeding $1,220 \mathrm{~m}(4,000 \mathrm{ft})$ thick, as well as significant sandstone development exceeding $300 \mathrm{~m}(1,000 \mathrm{ft})$ throughout most of the basin (Figure 5). In the deeper parts of the basin, sandstones within the isopach interval include primarily Sespe through Pico formation sandstones. Increasing contributions of Cretaceous strata, at the expense of these Eocene through Pliocene deposits, occupy the isopach interval in the shallower basin margins.

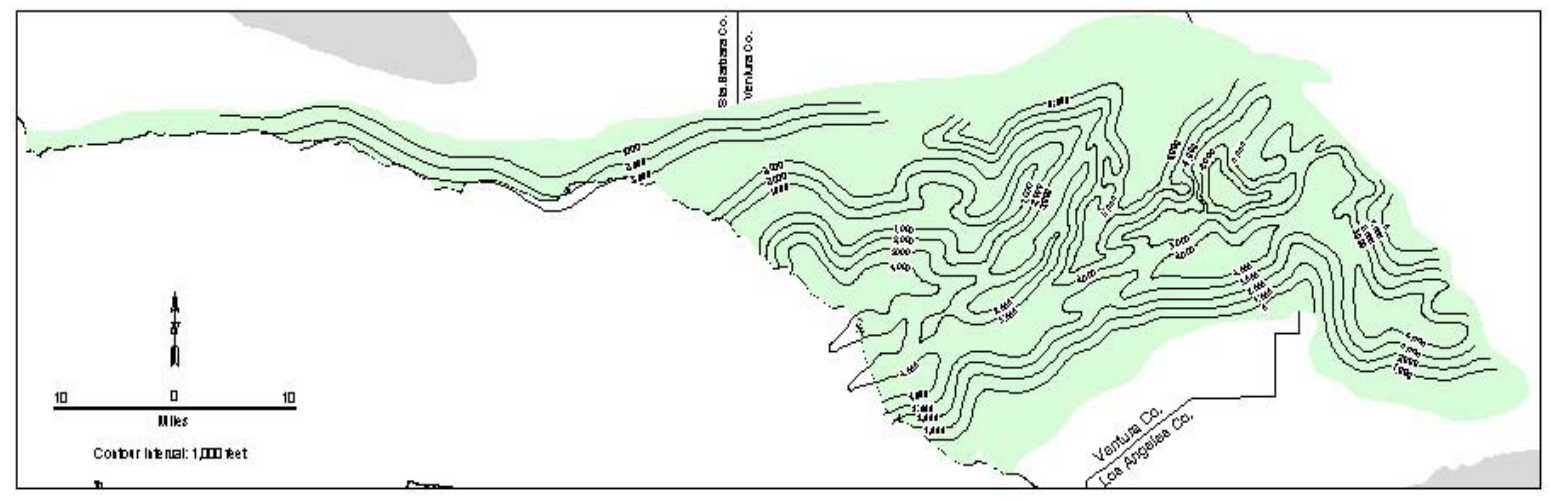

Figure 5. Generalized sandstone isopach map for the Ventura Basin 
The Peninsular Ranges are a series of mountain ranges in southwest coastal California characterized by intervening northwest-trending valleys subparallel to faults branching from the San Andreas Fault zone. The Peninsular Ranges are bordered on the north by the Transverse Ranges, on the west by the Channel Islands, and on the east by the Colorado Desert province. The Los Angeles Basin is the largest of the Peninsular Range basins. It is a structurally complex basin located within the San Andreas Transform system at the intersection of the Peninsular Ranges and Transverse Ranges. It covers about 3,890 km² (1,500 square miles) and is bordered on the north by the Santa Monica-HollywoodRaymond Hill Fault Zone and the Santa Monica Mountains; on the northeast by the Sierra Madre Fault and the San Gabriel Mountains; on the east and southeast by the Chino Fault, Santa Ana Mountains, and the San Joaquin Hills; and on the west and southwest by the Palo Verdes Fault. The basin contains a thick section of primarily Miocene and Pliocene sedimentary rocks estimated to be over 8,200 m (27,000 ft) thick. A generalized cross section is shown in Figure 6. The basin is considered the world's richest in terms of hydrocarbons per unit volume of sedimentary fill and contains three supergiant fields - the Wilmington, Huntington Beach, and Long Beach fields. Major oilproducing formations include the Puente and Repetto sandstones, with porosities ranging from 15 to $35 \%$ and permeabilities ranging from $9.9 \times 10^{-15}$ to $3.2 \times 10^{-12} \mathrm{~m}^{2}$ (10 to 3,200 md; DOGGR, 1991). Porosity and permeability decrease with depth.
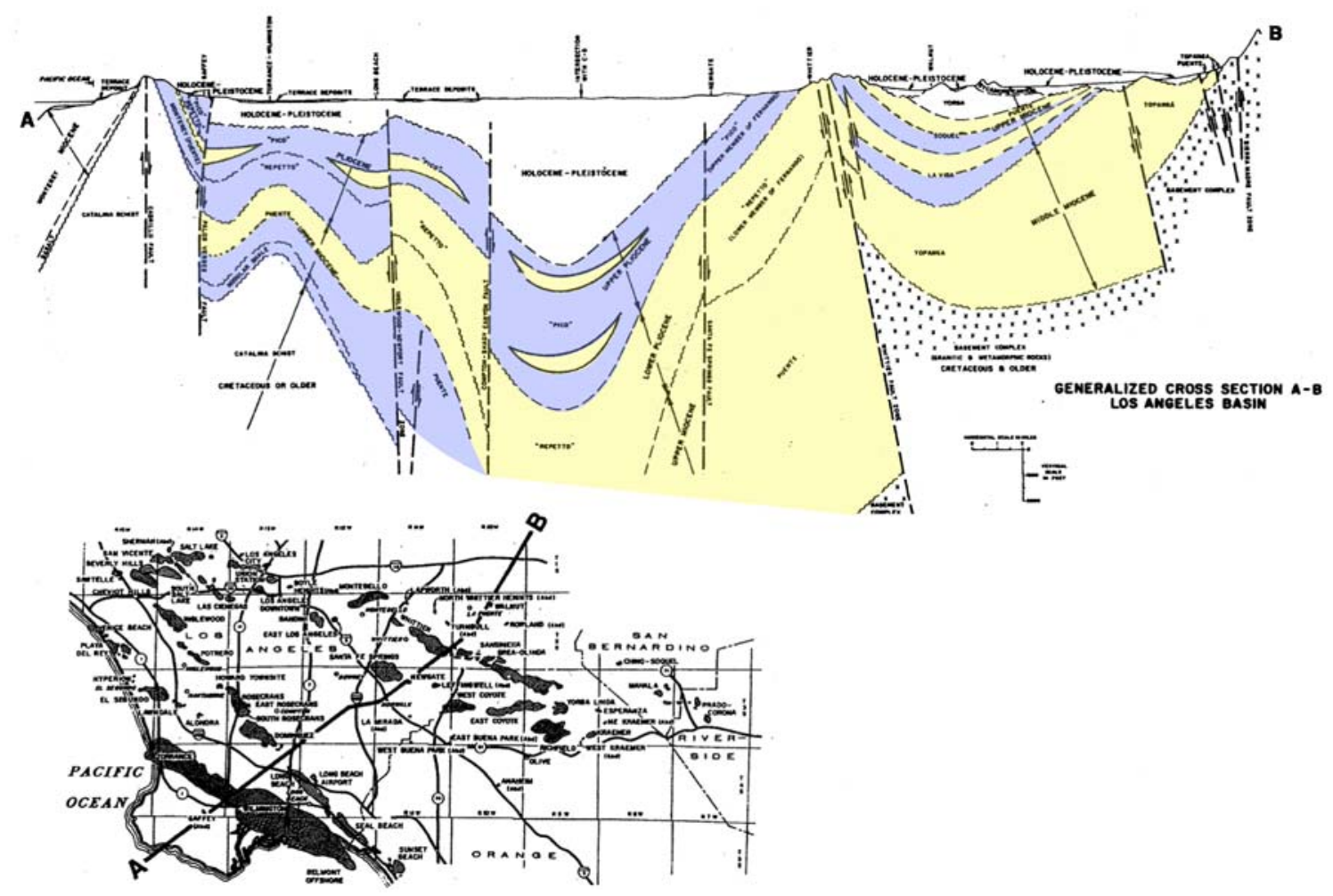

Figure 6. Generalized cross section through the Los Angeles Basin (adapted from DOGGR, 1991) 
A sandstone isopach map for the Los Angeles Basin indicates that more than $1,520 \mathrm{~m}$ $(5,000 \mathrm{ft})$ of sandstone is present within the isopach interval in the central basin, and that sandstone thickness generally correlates with relative basement depth (Figure 7). The thicker sandstone reflected in the basin center is dominated by Puente, Repetto, and Pico formation sandstones but, in the shallower basin margins, Topanga Formation and older units become locally important in the mapped interval.

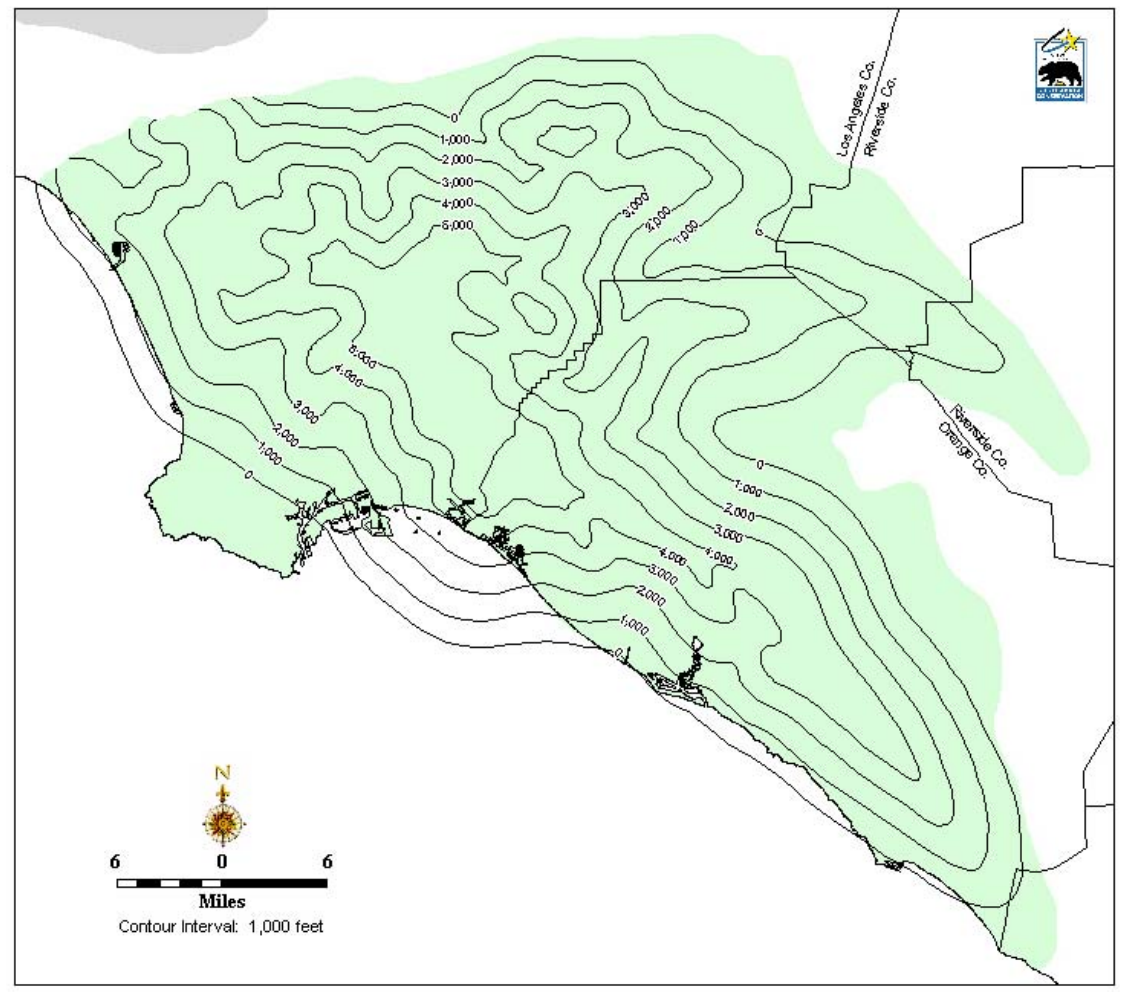

Figure 7. Generalized sandstone isopach map for the Los Angeles Basin

The Eel River, Livermore, Orinda, La Honda, Salinas, and Cuyama marine basins are all found in the Coast Ranges. California's Coast Ranges are composed of a series of northwesterly trending coastal mountain ranges and valleys extending southward from the Oregon state line to the Transverse Ranges in Santa Barbara and Ventura counties. To the east, they are bounded by the Coast Range Thrust, along which older Mesozoic rocks are thrust over Cretaceous rocks of the Great Valley Sequence in the Sacramento and San Joaquin basins.

The Eel River Basin, located in Humboldt County, is the onshore expression of a much larger offshore Cenozoic forearc basin. The onshore portion is expressed as a westerly plunging syncline. While the Freshwater Fault technically bounds the basin on the northeast, its northeast margin is more practically defined by the northeasterly dipping Little Salmon Thrust Fault. To the south, the basin is bounded by the Russ Fault, north of 
which the upturned beds of the Yager Formation and lower Wildcat Group are exposed. The basin contains more than $3,800 \mathrm{~m}(12,500 \mathrm{ft})$ of sedimentary fill, including over $3,350 \mathrm{~m}$ (11,000 ft) of dominantly Neogene marine, sandstone, siltstone, and shale resting on sandstones, conglomerates, and shales of the Cretaceous Yager Formation. Sandstones in the Bear River Beds through Rio Dell Formation may provide carbon sequestration opportunities in the deeper parts of the basin, on anticlinal closures and flanking stratigraphic pinch-outs. While individual sandstones are generally thin, a sandstone isopach map reveals a northwesterly trending zone of sandstone in excess of $760 \mathrm{~m}(2,500 \mathrm{ft})$ thick paralleling the north flank of the basin (Figure 8). Enclosing siliceous mudstones and shales should provide seals. Porosities of the sandstones range from 12 to $30 \%$ and permeabilities range from $9.9 \times 10^{-16}$ to over $3.0 \times 10^{-13} \mathrm{~m}^{2}$ (1 md to over 300 md; Stanley, 1995b; DOG, 1983).

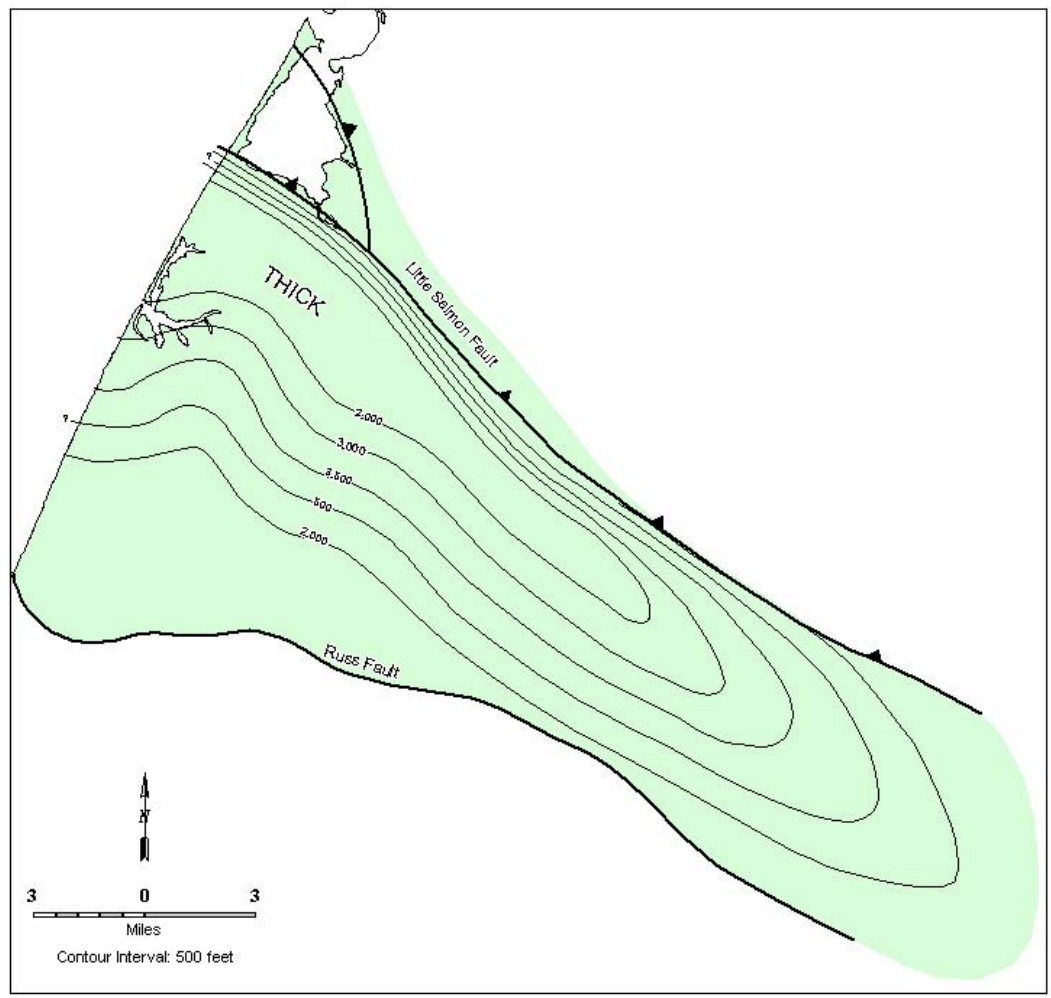

Figure 8. Generalized sandstone isopach map for the Eel River Basin

The Salinas Basin is one of several hydrocarbon-producing Cenozoic marine sedimentary basins west of the San Andreas Fault, including the La Honda Basin to the northwest and the Cuyama basin to the southeast. The basin is a narrow, northwest-trending feature extending almost $225 \mathrm{~km}$ (140 miles) from Monterey County southeastward into San Luis Obispo County, and varying in width from less than 16 to $48 \mathrm{~km}$ (10 to $30 \mathrm{miles}$ ). It is bordered on the east by the San Andreas Fault. To the northeast, the basin narrows where Salinian granitic basement rocks are uplifted and exposed in the Gabilan Range. The western basin margin is defined by the Jolan-Rinconda Fault Zone and uplifted 
granitic and metasedimentary rocks of the Santa Lucia Range. The structural and lithologic framework of the Salinas Basin consists of a series of tectonic basement blocks assembled during a complex history of subduction and transform motion along plate boundaries.

The Monterey formation sandstones are hydrocarbon producers and are potential sequestration targets in the Salinas Basin. Porosities in the shallow sands range from 15 to $39 \%$ with permeabilities of $4.9 \times 10^{-13}$ to $7.9 \times 10^{-12} \mathrm{~m}^{2}$ (500 to $8,000 \mathrm{md}$; DOGGR, 1991). While the Monterey sands in the known oil fields are too shallow for potential sequestration purposes, deeper Monterey sandstones exist farther west in the deeper basin. A gross sandstone isopach map (Figure 9) shows sandstone developments thickening to over $760 \mathrm{~m}(2,500 \mathrm{ft})$ to the southwest towards the basin axis. Underlying poorly known lower-middle Miocene and Cretaceous sandstones may also be present at depth.

The La Honda Basin is located north of the Salinas Basin in Santa Clara and Santa Cruz counties between San Francisco and Monterey Bay. The basin is bounded on the northeast by the San Andreas Fault, on the northwest by granitic rocks of Montara Mountain, on the southwest by the Zayante-Vergeles Fault, and on the west by the San Gregorgio-Hosgri Fault (Stanley, 1995a). The relatively small basin comprises about 930 $\mathrm{km}^{2}\left(360 \mathrm{mi}^{2}\right)$ and represents a small sliver of the larger San Joaquin Basin, which was displaced approximately $298 \mathrm{~km}$ (185 miles) by right lateral slip along the San Andreas

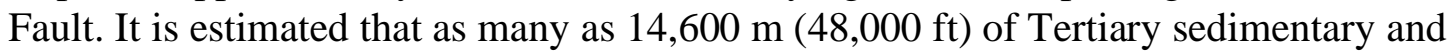
volcanic strata fill the basin. 


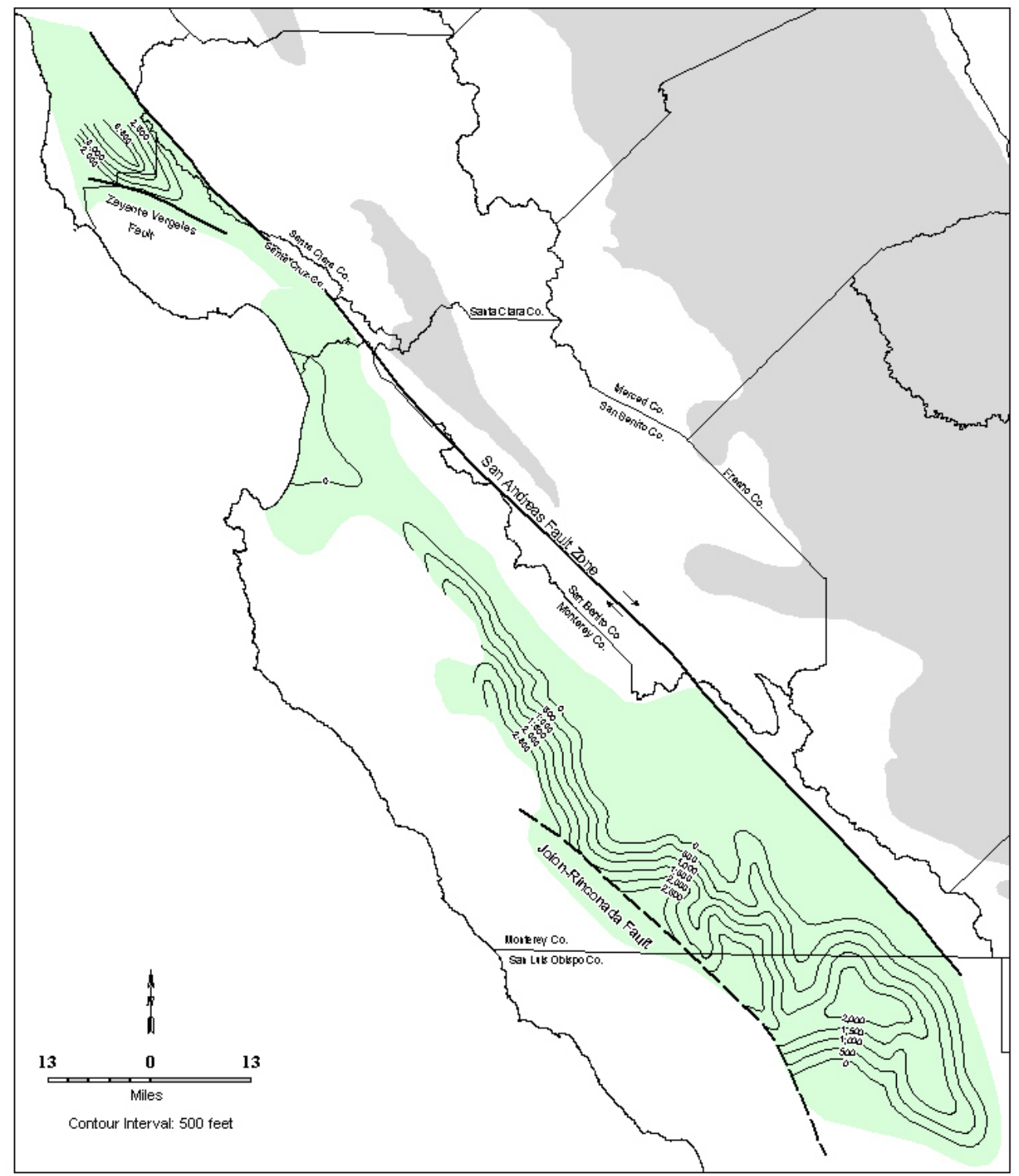

Figure 9. Generalized sandstone isopach map for the Salinas and La Honda Basins

In the eastern basin, the Butano and Locatelli formations are too shallow to be considered for $\mathrm{CO}_{2}$ sequestration. Westward, towards the basin center, however, sandstone in the Butano and younger formations thickens markedly (Figure 9). The deepest well in the basin, drilled on the Butano Anticline, bottomed in the Butano Formation at 3,370 m $(11,053 \mathrm{ft})$ and encountered more than 1,220 m (4,000 ft) of Butano sandstone within the isopach interval. The Vaqueros through Santa Margarita formations are blanketed by the Santa Cruz Mudstone and Purisima Formation, which can attain thicknesses of 2,700 m $(8,900 \mathrm{ft})$ and 2,400 $\mathrm{m}(7,900 \mathrm{ft})$, respectively. Shallow producing sands in the Butano between 550 and $760 \mathrm{~m}(1,800$ and 2,500 ft) deep exhibit porosities between 15 and 35\% with permeabilities of $3.0 \times 10^{-14}$ to $3.9 \times 10^{-14} \mathrm{~m}^{2}$ (30 to $40 \mathrm{md}$ ), but at depth, these are expected to be considerably reduced. Shallow Purisima sandstones between 240 and 820 
$\mathrm{m}\left(800\right.$ and 2,700 ft) deep exhibit porosities of 22 to $34 \%$ and permeabilities of $9.9 \times 10^{-16}$ to $3.9 \times 10^{-14} \mathrm{~m}^{2}$ (1 to $40 \mathrm{md}$; DOGGR, 1991).

The Cuyama Basin is a relatively small Cenozoic marine basin near the southern end of the Coast Ranges. It extends approximately 105 to $121 \mathrm{~km}$ (65 to 75 miles) in a northwest-southeast direction and varies from 13 to $29 \mathrm{~km}$ ( 8 to 18 miles) wide. It is bounded on the northeast by the San Andreas Fault zone and the Temblor Range, which separate it from the San Joaquin Basin. Its southwest margin is structurally complex and consists of at least two early Miocene wrench faults (Russell and La Panza Faults), which separate the basin from the Sierra Madre Range. The northwest end of the basin is indeterminate, but approaches the southeast end of the Salinas Basin. Its southeastern end is defined by a buried normal fault subparallel to the younger Big Pine Fault (Tennyson, 1995). The basin is structurally complex, with extensive normal faulting of the prePliocene section followed by later thrust faulting of the basement through the Pliocene section, burying much of the sedimentary section below complex thrust sheets.

In the north-central portion of the basin, where deep well control exists, a sandstone isopach map (Figure 10) indicates an area of thick sandstone exceeding 1,220 m (4,000 $\mathrm{ft}$ ) and aligned in a northwest-southeast orientation roughly paralleling the basin axis. Sandstones within the isopach interval include Branch Canyon and Painted Rock sandstones and overlying Santa Margarita sandstones. Porosities of the sandstones range from 19 to $40 \%$, and permeabilities range from $1.7 \times 10^{-13}$ to $1.3 \times 10^{-12} \mathrm{~m}^{2}$ (177 to 1,300 md; DOGGR, 1991).

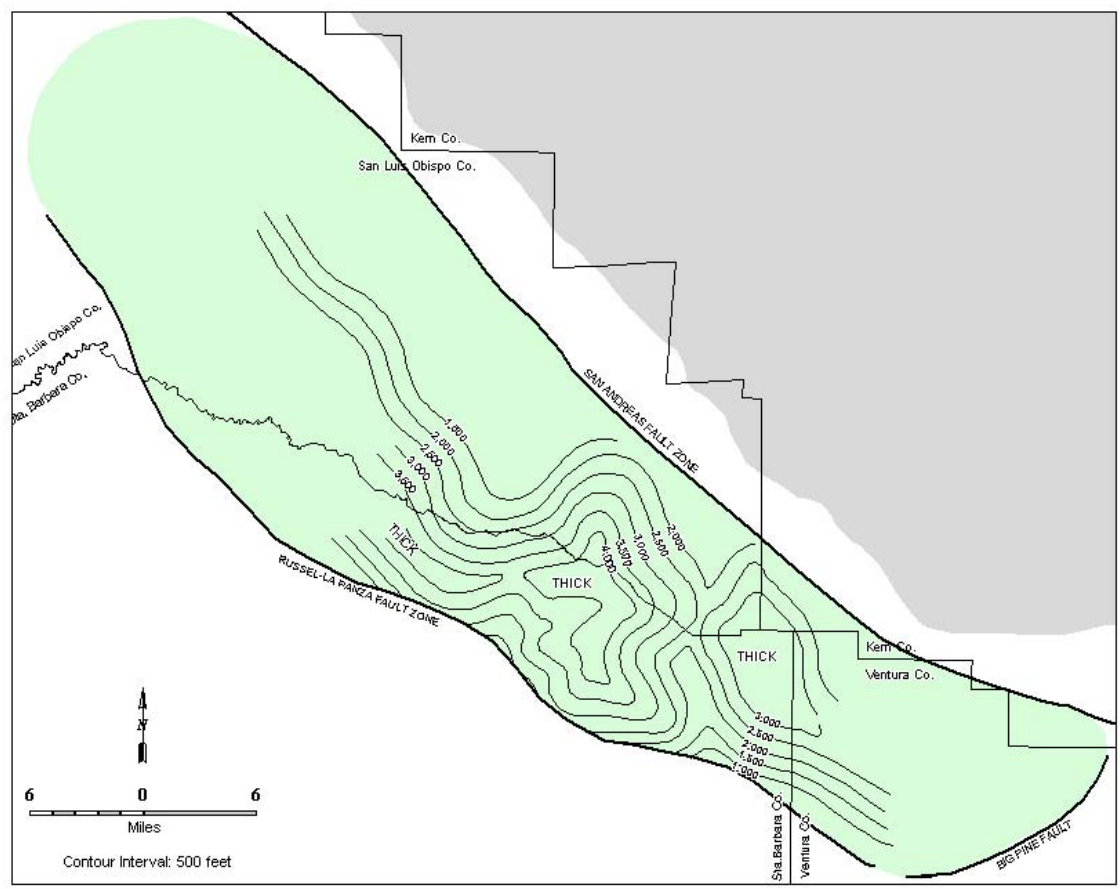

Figure 10. Generalized sandstone isopach map for Cuyama Basin 
The Livermore and Orinda basins are part of a related series of deep, linear, Neogene pull-apart basins within the Coast Ranges between San Francisco Bay and the Sacramento Basin. Both basins formed under the influence of extensional stresses after the onset of strike-slip motion along the San Andreas and associated Calaveras and Hayward fault systems during the middle Miocene. The Livermore Basin is approximately $48 \mathrm{~km}$ (30 miles) long by $19 \mathrm{~km}$ (12 miles) wide. It is bounded on the north and east by Mount Diablo and the Diablo Range, and on the west and southwest by the Calaveras Fault, which separates it from the Orinda Basin. Uplifted Franciscan Complex rocks form its southern end. While the deepest well drilled bottomed at 5,306 m $(17,404 \mathrm{ft})$ in Miocene sediments (Darrow, 1979), outcrop and unpublished geophysical data suggest that the Livermore Basin may be filled with as much as $6,700 \mathrm{~m}(22,000 \mathrm{ft})$ of Eocene, Miocene, and Pliocene sediments that have been extensively folded and faulted by later compressional forces caused by motion on the marginal faults.

A gross sandstone isopach map for the basin depicts an area of thicker sand development exceeding $490 \mathrm{~m}(1,600 \mathrm{ft})$ in the south central portion of the basin (Figure 11). Given the complex structural configuration of the basin, steep dips, and fault displacements along the basin margins, the isopach interval includes sandstones of the Cretaceous Panoche through Pliocene Orinda formations. Limited data on porosity and permeability yield values of about $25 \%$ and $2.5 \times 10^{-13} \mathrm{~m}^{2}$ (250 md), respectively (DOG, 1983). 


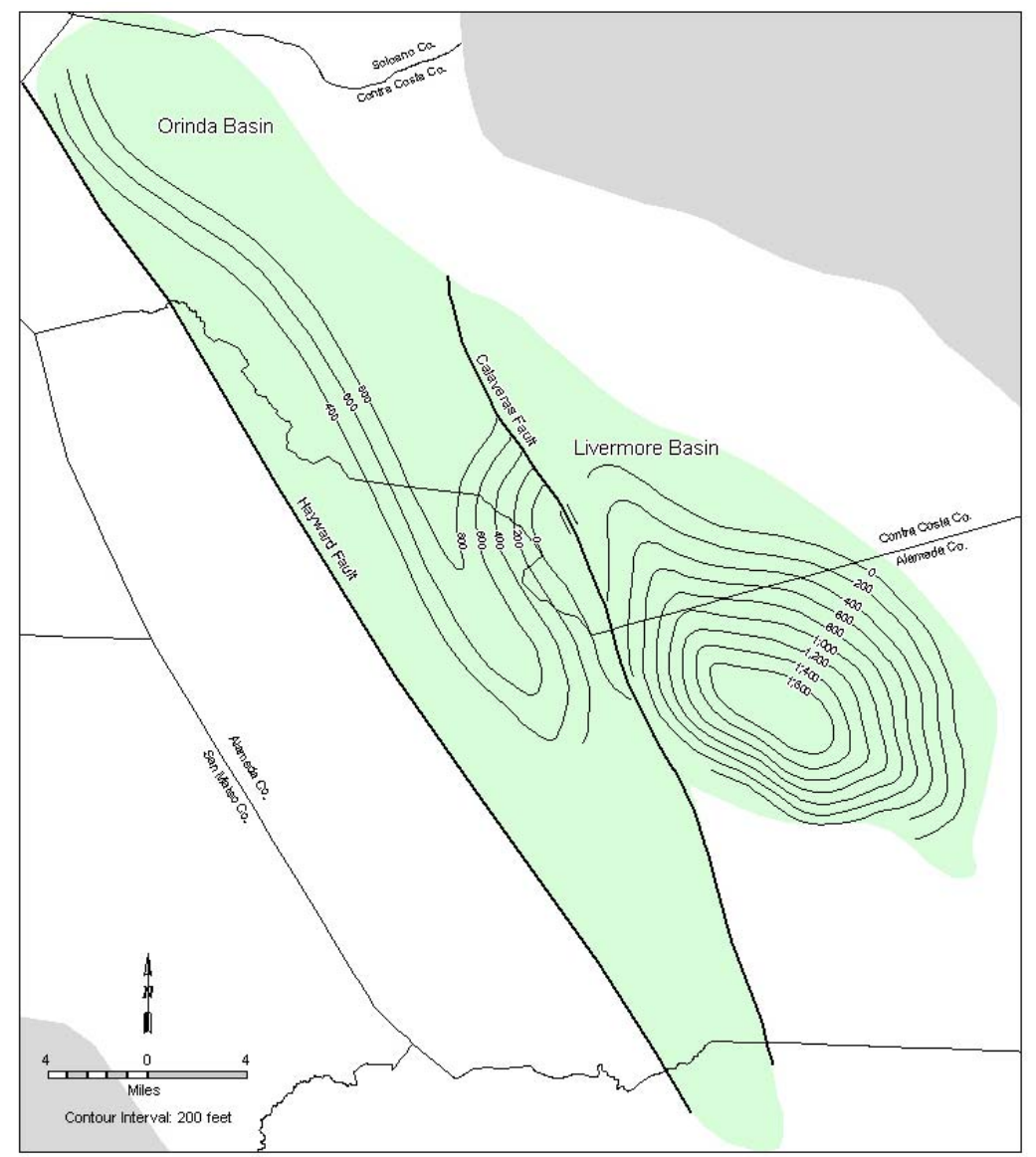

Figure 11. Generalized sandstone isopach map for Livermore and Orinda Basins

The Orinda Basin is a narrow linear basin measuring about $81 \mathrm{~km}$ (50 miles) by $11 \mathrm{~km}(7$ miles), bounded on the west by the Hayward Fault and on the east by the Calaveras Fault. Its southern limit is the convergence of the two faults in northern Santa Clara County. Its northern end is taken to San Pablo Bay, past which the Sonoma Basin begins. Limited well control and outcrop data indicates the Orinda Basin contains a sedimentary section very similar to that of the neighboring Livermore Basin. The deepest well bottomed at $3,048 \mathrm{~m}(9,997 \mathrm{ft})$ in the abandoned one-well Pinole Point Field near the north end of the basin. Only two other wells exceeded $2,700 \mathrm{~m}(9,000 \mathrm{ft})$ with a handful going to 1,500$2,100 \mathrm{~m}(5,000-7,000 \mathrm{ft})$. The available well logs were used to construct a sandstone isopach map of logged section, which suggests a longitudinal thickness of at least $240 \mathrm{~m}$ (800 ft) extending from near the basin center to San Pablo Bay (Figure 11).

\subsubsection{Capacity Assessment}

Isopach and depth-to-basement maps were used to estimate the total storage capacity within saline formations in the ten largest sedimentary basins. Table 4 provides the data used to calculate the total available pore volume in the basins. Only a portion of the total pore volume is available for storage. The storage capacity is determined from the mass of $\mathrm{CO}_{2}$ trapped in the pore space either as a separate phase or dissolved in the pore water. 
Table 4. Data used for calculation of pore volume of California basins

\begin{tabular}{|c|c|c|c|}
\hline \multicolumn{4}{|c|}{ Volumetric Data for California Basins } \\
\hline & $\begin{array}{c}\text { Area } \\
\text { (sq. miles)+ }\end{array}$ & $\begin{array}{c}\text { Estimated Average } \\
\text { Thickness in m (ft) }\end{array}$ & $\begin{array}{c}\text { Estimated } \\
\text { Average } \\
\text { Porosity }\end{array}$ \\
\hline \hline Sacramento-San Joaquin basins & 18,550 & $610(2,000)$ & 0.25 \\
\hline Los Angeles Basin & 1,341 & $920(3,000)$ & 0.25 \\
\hline Ventura Basin & 1,450 & $920(3,000)$ & 0.24 \\
\hline Salton Trough & 2,559 & $610(2,000)$ & 0.24 \\
\hline Eel River Basin & 175 & $460(1,500)$ & 0.26 \\
\hline Salinas Basin & 1,343 & $460(1,250)$ & 0.28 \\
\hline La Honda Basin & 268 & $460(1,500)$ & 0.25 \\
\hline Livermore Basin & 144 & $240(800)$ & 0.23 \\
\hline Orinda Basin & 296 & $180(600)$ & 0.23 \\
\hline \multicolumn{2}{|c|}{ Cuyama Basin } & 582 & 0.27 \\
\hline \multicolumn{2}{|c|}{} & & \\
\hline${ }^{*}$ Area of basin at depths greater than $800 \mathrm{~m}(2,625 \mathrm{ft})$ & $(3,000)$ & \\
\hline${ }^{*}$ Average sands (isopachs) thickness for depth window $800-3,050 \mathrm{~m}(2,625-10,000 \mathrm{ft})$ & \\
\hline${ }^{*}$ Approx. average porosity for all zones in isopachs window & \\
\hline
\end{tabular}

Many factors affect the percentage of the pore space that could be occupied, including formation heterogeneity, buoyant flow, hydrologic boundary conditions, residual saturation, and other two-phase flow properties. Reservoir modeling studies also suggest that, because of two-phase conditions and diffusion, the pore volume containing dissolved $\mathrm{CO}_{2}$ will be greater than the pore volume of separate-phase $\mathrm{CO}_{2}$. Two other factors affecting storage capacity are the density of the in-place $\mathrm{CO}_{2}$ and the salinity of the pore water. Formation temperature and allowable injection pressures will, in large part, determine the $\mathrm{CO}_{2}$ density. Salinity of the pore waters is important because $\mathrm{CO}_{2}$ solubility decreases with increasing salinity.

Figure 12 shows the results of capacity calculations for a range of pore-volume values containing separate-phase and dissolved $\mathrm{CO}_{2}$. The calculations assumed a single density value of $600 \mathrm{~kg} / \mathrm{m}^{3}$ and a $\mathrm{CO}_{2}$ dissolved mass fraction of $2.5 \%$. Results show total storage capacity for the 10 basins ranging from about $150 \mathrm{Gt}$ to about $500 \mathrm{Gt}$. The low end of this range would provide sufficient capacity for storing over 1,000 years of utility and industrial sector emissions at the current emission rates. Table 4 shows that more than half of this capacity is contained in the Sacramento-San Joaquin basins. 


\section{Range of Saline Formation Capacity}

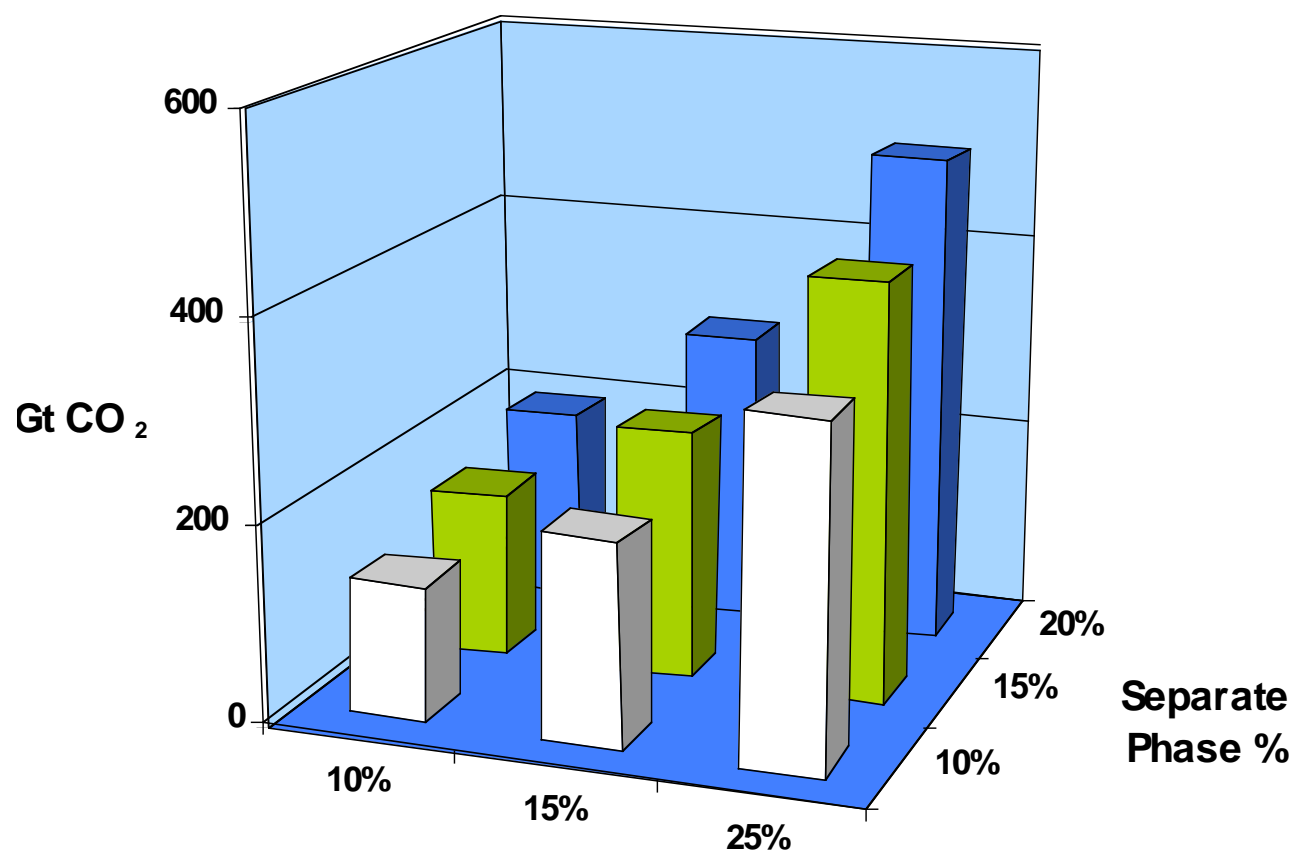

\%Pore Volume Occupied

Figure 12. Total sequestration capacity of saline formations in ten largest basins in California

Several of the sedimentary basins, notably the Sacramento, San Joaquin, Los Angeles, and Ventura basins, also contain major oil and gas fields, which will likely be the first targets for geologic sequestration. Estimates for the $\mathrm{CO}_{2}$ storage capacity of California oil and gas fields were based upon production data using Elewaut et al., 1996:

$$
Q_{\mathrm{CO} 2}=\left(V_{U o i l}+V_{U g a s}\right) * \rho_{\mathrm{CO}_{2}} / 1,000
$$

where

$$
\begin{aligned}
& Q_{\mathrm{CO} 2}=\mathrm{CO}_{2} \text { storage capacity }\left(\mathrm{MtCO}_{2}\right) \\
& V_{\text {Uoil }}=\text { underground volume of oil produced }\left(\mathrm{M} \mathrm{m}^{3}\right) \\
& V_{U g a s}=\text { underground volume of gas produced }\left(\mathrm{M} \mathrm{m}^{3}\right), \text { and } \\
& \rho_{\mathrm{CO}_{2}}=\mathrm{CO}_{2} \text { density at the reservoir pressure. }
\end{aligned}
$$

The underground volume of oil and gas was estimated from:

$$
V_{U o i l}=V_{o i l(s t)} * B_{o}
$$




$$
V_{U g a s}=V_{g a s(s t)} * B_{g}
$$

where

$$
\begin{aligned}
& V_{\text {oil }(s t)}=\text { Volume of oil at standard conditions }\left(\mathrm{M} \mathrm{m}^{3}\right) \\
& V_{g a s(s t)}=\text { Volume of gas at standard conditions }\left(\mathrm{M} \mathrm{m}^{3}\right) \\
& B_{o}=\text { Oil formation volume factor }(\mathrm{FVF}), \text { and } \\
& B_{g}=\text { Gas formation volume factor }\left(\mathrm{E}^{-1}\right) .
\end{aligned}
$$

A default FVF of 1.2 was applied for oil. The gas expansion factor $\mathrm{E}$ was calculated with linear relation: $\mathrm{E}=4.8 \mathrm{P}+93.1$, where $\mathrm{P}$ is the reservoir pressure in $\mathrm{MPa}$. If the original reservoir pressure value were missing, it was calculated from the average depth of the field, assuming a gradient of $10.5 \mathrm{MPa} / \mathrm{km}$.

An estimate of the $\mathrm{CO}_{2} \mathrm{EOR}$ potential for oil fields was made based on API gravity data and depth. Oil fields at depths greater than $915 \mathrm{~m}(3,000 \mathrm{ft})$ and with API gravity more than $25^{\circ}$ were classified as fields with miscible $\mathrm{CO}_{2}$-EOR potential. Fields at depths greater than $915 \mathrm{~m}(3,000 \mathrm{ft})$ and with API gravity between $17.5^{\circ}$ and $25^{\circ}$ were classified as fields with immiscible $\mathrm{CO}_{2}$-EOR potential. Fields at depths greater than $915 \mathrm{~m}(3,000$ $\mathrm{ft}$ ) and API gravity less than $17.5^{\circ}$ were classified as fields with storage potential but no EOR potential. The attributed GIS database was interrogated using these criteria, yielding 121 fields in California with miscible $\mathrm{CO}_{2}$ EOR potential and a $\mathrm{CO}_{2}$ storage capacity of $3.4 \mathrm{Gt}$. The storage capacity was increased to $3.8 \mathrm{Gt}$ by including the fields in the remaining two categories. Though tiny compared to the total saline formation capacity, the storage capacity associated with potential $\mathrm{CO}_{2} \mathrm{EOR}$ is still equal to over 27 years of current utility and industrial sector emissions.

The capacity of California gas fields, screened by depth, was also estimated using the expression in Equation 1. The result yielded 128 gas fields with a combined storage capacity of $1.8 \mathrm{Gt}$. Oldenburg et al. (2001) have shown that $\mathrm{CO}_{2}$ can be used to enhance production from depleting gas fields (EGR), though an estimate of the $\mathrm{CO}_{2} \mathrm{EGR}$ potential for California has yet to be done.

\subsection{Oregon and Washington}

\subsubsection{Sedimentary Basins}

In Oregon and Washington, the most promising near-term sedimentary basin targets are found in the Coastal Ranges and Puget-Willamette Lowlands geomorphic provinces, though several interior basins may also be important because of the location of large emission sources (Figure 13). The Coastal Ranges and Puget-Willamette Lowlands provinces are the home of a major Tertiary sedimentary belt of basins that formed in a regional fore-arc environment as the Juan de Fuca plate subducted beneath the North American Plate. These basins, the boundaries of which are uncertain at this time, are characterized by up to $6,100 \mathrm{~m}(20,000 \mathrm{ft})$ of Tertiary sedimentary rocks deposited in 
embayments and shallow seas. Results for these basins are summarized in the following pages. More detailed information on these as well as other basins in Oregon and Washington is found in Golder Associates, 2005.

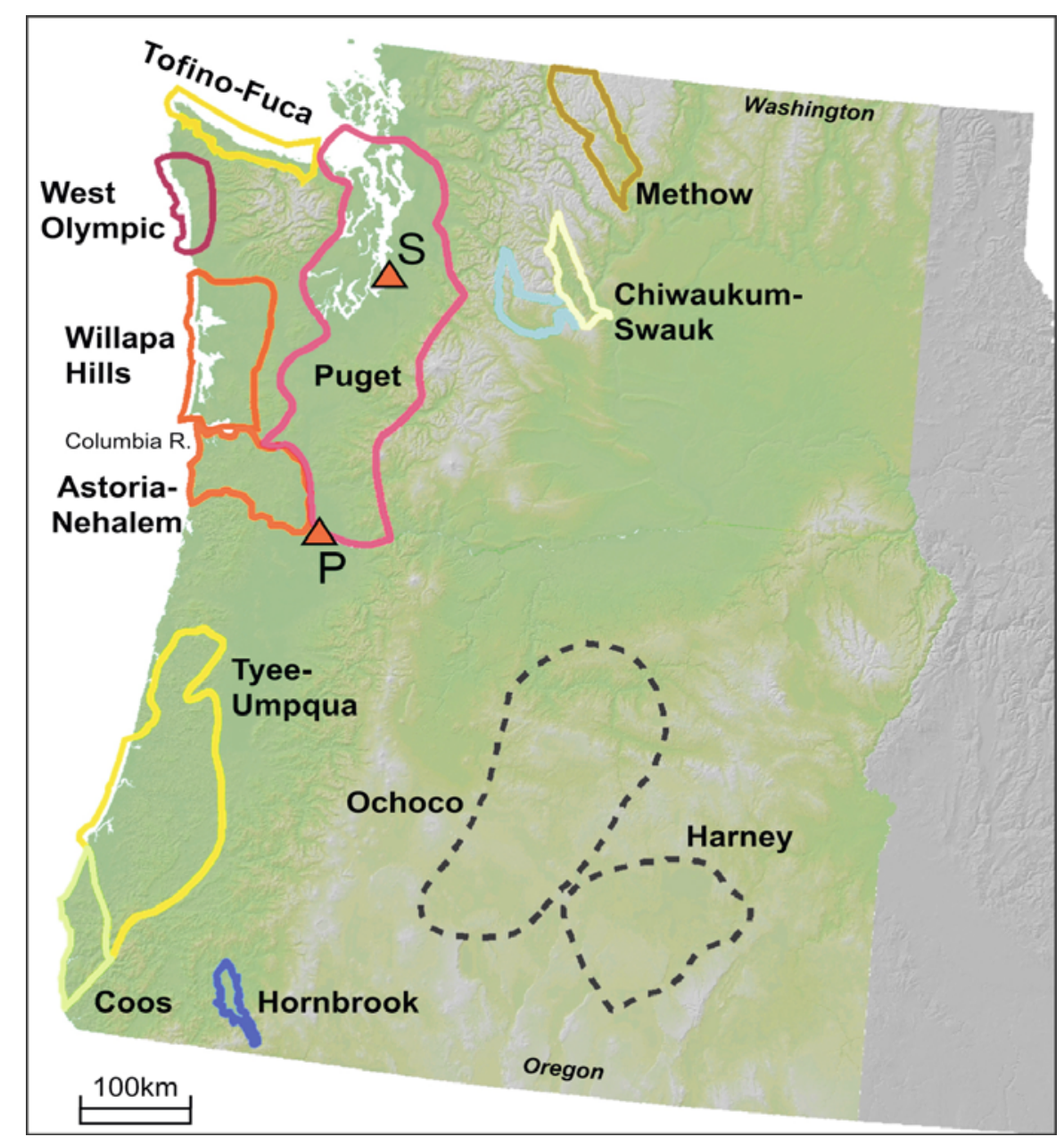

Figure 13. Sedimentary basins in Oregon and Washington. $S=$ Seattle, Wash. $P=$ Portland, Ore.

Three basins are found in the Coastal Ranges of Washington: Tofino-Fuca Basin, Western Olympic Basin, and Willapa Hills Basin. Of these, the Western Olympic and Willapa Hills Basins are the most promising. The Western Olympic Basin is located directly west of the Olympic Mountains in Clallam and northern Jefferson Counties, and extends westwards offshore for at least 40 miles (Wagner and Batatian, 1985). The sedimentary strata have an estimated total thickness of at least 2,700 m (9,000 ft; Figure 14), and the recognized formations are:

- Quinault Formation-Pliocene-Miocene (PLMn), up to 1,500 m (5,000 ft) of nearshore sedimentary rocks (siltstone, sandstone and conglomerate); and 
- Hoh Assemblage-lower-mid Eocene, a sequence of marine rocks accreted to the continental margin:

○ Lincoln Creek Formation-Oligocene-Eocene; up to 2,700 m (9,000 ft) of massive sandstones and tuffaceous siltstones;

- Skookumchuck Formation-mid-upper Eocene, up to $1,100 \mathrm{~m}(3,500 \mathrm{ft})$ of interbedded shallow marine and continental facies (arkosic sandstones and siltstone), and coal in upper and lower member; and

o McIntosh Formation-mid-upper Eocene, up to $1,500 \mathrm{~m}(5,000 \mathrm{ft})$ of tuffaceous sedimentary rocks.

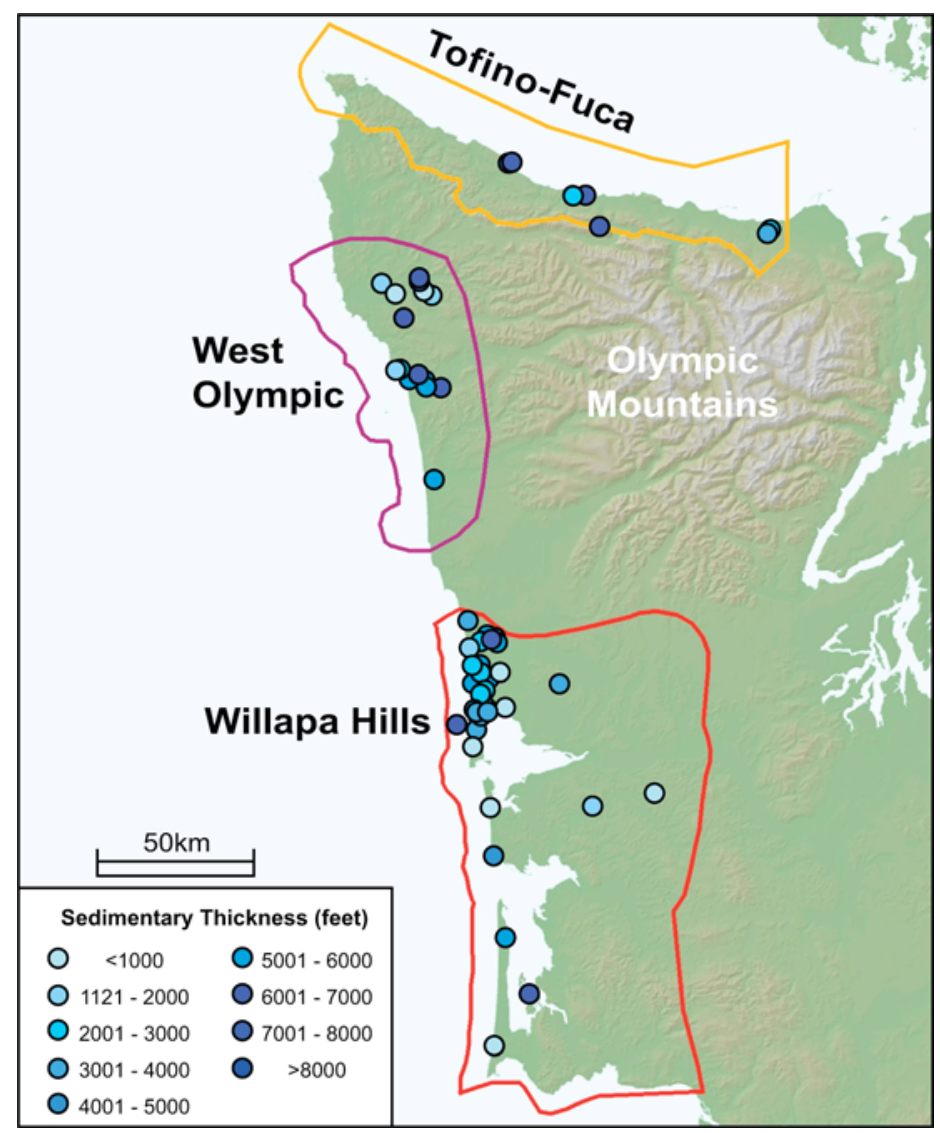

Figure 14. Sediment thickness in basins of Coastal Ranges of Washington

The basin is tectonically active and the sediments are highly deformed; some structural traps are present. The sandstones have porosities of 36-46\% and permeabilities of $1.0 \times 10^{-13}$ to $9.1 \times 10^{-13} \mathrm{~m}^{2}$ (102 to $917 \mathrm{md}$ ).

The Willapa Hills (Grays Harbor) Basin are topographic hills that rise to about $950 \mathrm{~m}$ $(3,100 \mathrm{ft})$ above sea level and are situated between the Olympic Mountains to the north 
and the Columbia River to the south. The basin contains up to 4,600 m (15,000 ft; Figure 14) of late Oligocene to Quaternary strata overlying basement/broken mélange of midMiocene to early Oligocene age. Eocene and Oligocene sediments consist predominantly of deep-water siliciclastics, and arkosic sandstones; interbedded volcaniclastic sandstones are contained within thick marine shale sequences.

The recognized geologic formations in the basin above the Crescent Formation are:

- Quinault Formation-Pliocene-Miocene (PLMn), nearshore sedimentary rocks (siltstone, sandstone, and conglomerate);

- Montesano Formation-mid-upper Miocene $(\mathrm{Mm}(2 \mathrm{~m}))$, up to $920 \mathrm{~m}$ (3,000 ft) of fluvial, lacustrine, brackish water, and shallow marine sediments;

- Astoria Formation-lower-mid Miocene, Mm(1a), up to 1,100 m (3,500 ft) of marine sedimentary rocks (carbonaceous, fine-grained sandstone);

- Hoh Assemblage - similar sequence to that in the Western Olympic Basin;

- Cowlitz Formation-Eocene (En(c) or Tco), unconformably overlies the Crescent Formation and contains marine/nonmarine siltstone and sandstone; and

- Northcraft Formation-Eocene $(\operatorname{Evc}(n))$, up to $460 \mathrm{~m}(1,500 \mathrm{ft})$ of volcaniclastic deposits and lavas.

The Willapa Hills basin is the most promising Coastal Range Basin for hydrocarbon development, and therefore $\mathrm{CO}_{2}$ storage, because of the deep-water sandstones, thick shales and claystones, and anticlinal traps. Sandstones of the Montesano Formation have porosities of $6.4-32.7 \%$ and permeabilities up to $5.2 \times 10^{-13} \mathrm{~m}^{2}(522 \mathrm{md})$.

The Puget Trough Basin is located in northwestern Washington, and occupies the generally low-lying region east of the Olympic Mountains and west of the Cascade Mountains. The southern extent of the basin is defined by the mergence of the Cascade Range and Coastal Range in Lewis and Cowlitz counties. The basin consists of up to $1,100 \mathrm{~m}(3,700 \mathrm{ft})$ of unconsolidated sediments of Pleistocene age overlying up to 3,050 $\mathrm{m}(10,000 \mathrm{ft})$ of Tertiary sedimentary rocks. The geology of the Puget Trough is complex, and interpretation is made difficult by the large volume of mostly glacially derived, unconsolidated sediments. Faulting and folding is abundant, and many active faults are recognized. The faulting has resulted in the formation of several major subbasins (Figure 15):

- Everett Sub-basin — bounded to the north and south by the North and South Whidbey Island Fault Zones, respectively, and attains a maximum thickness of between 3,050 and 4,300 $\mathrm{m}(10,000$ and 14,000 ft), of which as much as 1,100 m $(3,600 \mathrm{ft})$ is considered to be unconsolidated sediments (Jones, 1999);

- Seattle Sub-basin-located south of the South Whidbey Island fault, is bounded to the south by the Seattle fault and uplift, and contains up to 4,600 $\mathrm{m}(15,000 \mathrm{ft})$ of sedimentary material, of which up to $1,100 \mathrm{~m}(3,700 \mathrm{ft})$ is unconsolidated; 
- Tacoma Sub-basin - located south of the Narrows Structure, up to $1,800 \mathrm{~m}(6,000$ $\mathrm{ft}$ ) thick (610 m, or 2,000 ft, of unconsolidated sediments); and

- Chehalis Sub-basin —occupies the southern portion of the Trough, south of the Olympic Gravity Anomaly; the unconsolidated sediment thickness is less than $120 \mathrm{~m}(400 \mathrm{ft})$ here.

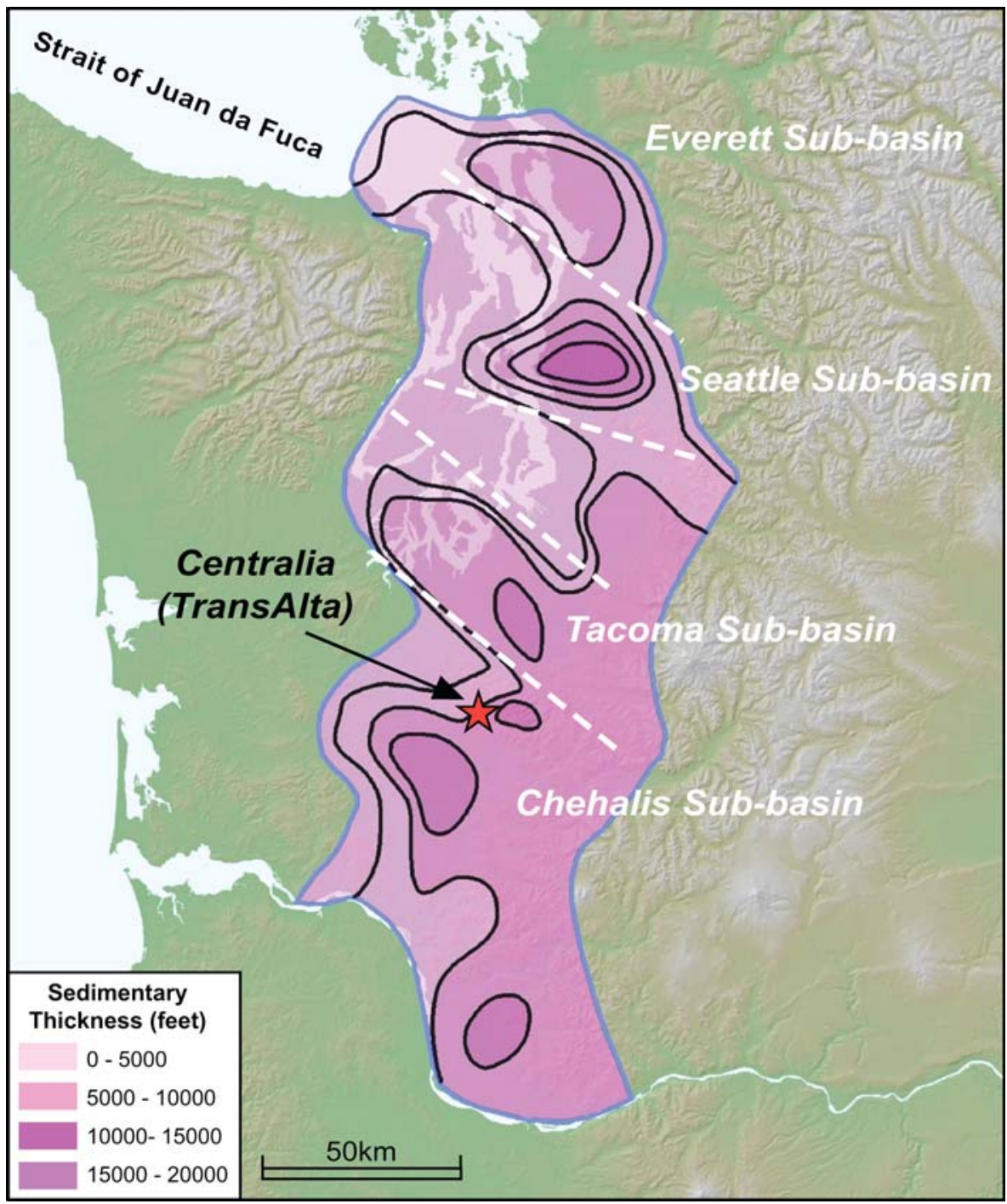

Figure 15. Sedimentary sub-basins in the Puget Trough of Washington. The location of the TransAlta power plant in Centralia, Wash., is noted. 
The key sedimentary formations in the Everett-Seattle-Tacoma sub-basins are:

- Blakeley and Blakeley Harbor Formations-Oligocene-Eocene (OEm(b)), marine sedimentary rocks in the northern Puget Sound area of interbedded volcaniclastic sandstone, siltstone, shale, and conglomerate;

- Puget Group-Eocene (Ec(2pg)), continental sedimentary rocks/deposits;

- Renton Formation $(\mathrm{Ec}(2 \mathrm{r})$ )—continental sedimentary rocks/deposits (fine- to medium-grained, massive to cross-bedded arkosic sandstone);

- Tiger Mountain Formation (Ec(2t))—continental sedimentary rocks/deposits; and

- Tukmila Formation $(\operatorname{Evc}(\mathrm{t}))$ - volcaniclastic rocks/deposits (sandstone, siltstone, and conglomerate).

The Chehalis Sub-basin occupies the lowland area between the southern extent of Puget Sound in Thurston County, extending into Lewis County and northernmost Cowlitz County. The basin contains up to $4,600 \mathrm{~m}(15,000 \mathrm{ft})$ of sedimentary sequence. The key sedimentary formations are:

- Wilkes Formation-Miocene $(\mathrm{Mc}(\mathrm{w}))$, continental sedimentary rocks; and

- Hoh Assemblage-lower-mid Eocene, a sequence of marine rocks accreted to the continental margin; includes the Lincoln Creek, Skookumchuck, and McIntosh Formation. Both basal Lincoln Creek Sandstone and Skookumchuck sandstones serve as reservoirs in the Jackson Prairie Gas Storage Field.

Sandstones of the Skookumchuck have porosities of 30-38\% and permeabilities of $1.3 \times 10^{-13}$ to $3.0 \times 10^{-12} \mathrm{~m}^{2}$ (135 to $3,000 \mathrm{md}$ ).

The Puget Trough Basin also contains deep coal formations, which are sequestration targets and may have potential for ECBM. Coals in this region occur within the Puget Group. Figure 16 provides an initial assessment of the subsurface extent of the coal basins, showing deep coals to be present over an area of approximately $2,500 \mathrm{~km}^{2}$. Coal rank (thermal maturity) is an important factor to consider when assessing coal seams for coalbed methane and for sequestration potential. In general, coal rank increases from northwest to southeast in the Puget region, reflecting greater tectonic deformation and heat associated with Cascade Range uplift. Initial analysis indicates excellent coal seam reservoir properties: $30 \mathrm{~m}$ (100 ft) coal thickness (in the Skookumchuck formation), 20$24 \mathrm{G}\left(\mathrm{m}^{3}\right) /$ ton $\left(700-850 \mathrm{ft}^{3} / \mathrm{ton}\right) \mathrm{CO}_{2}$ sorption capacity, and $4.9 \times 10^{-15} \mathrm{~m}^{2}(5 \mathrm{md})$ permeability. The amount of unmineable coal in the Puget Sound basin was estimated to be over 70 billion tons, with a $\mathrm{CO}_{2}$ storage potential of $2.8 \mathrm{Gt}$. 


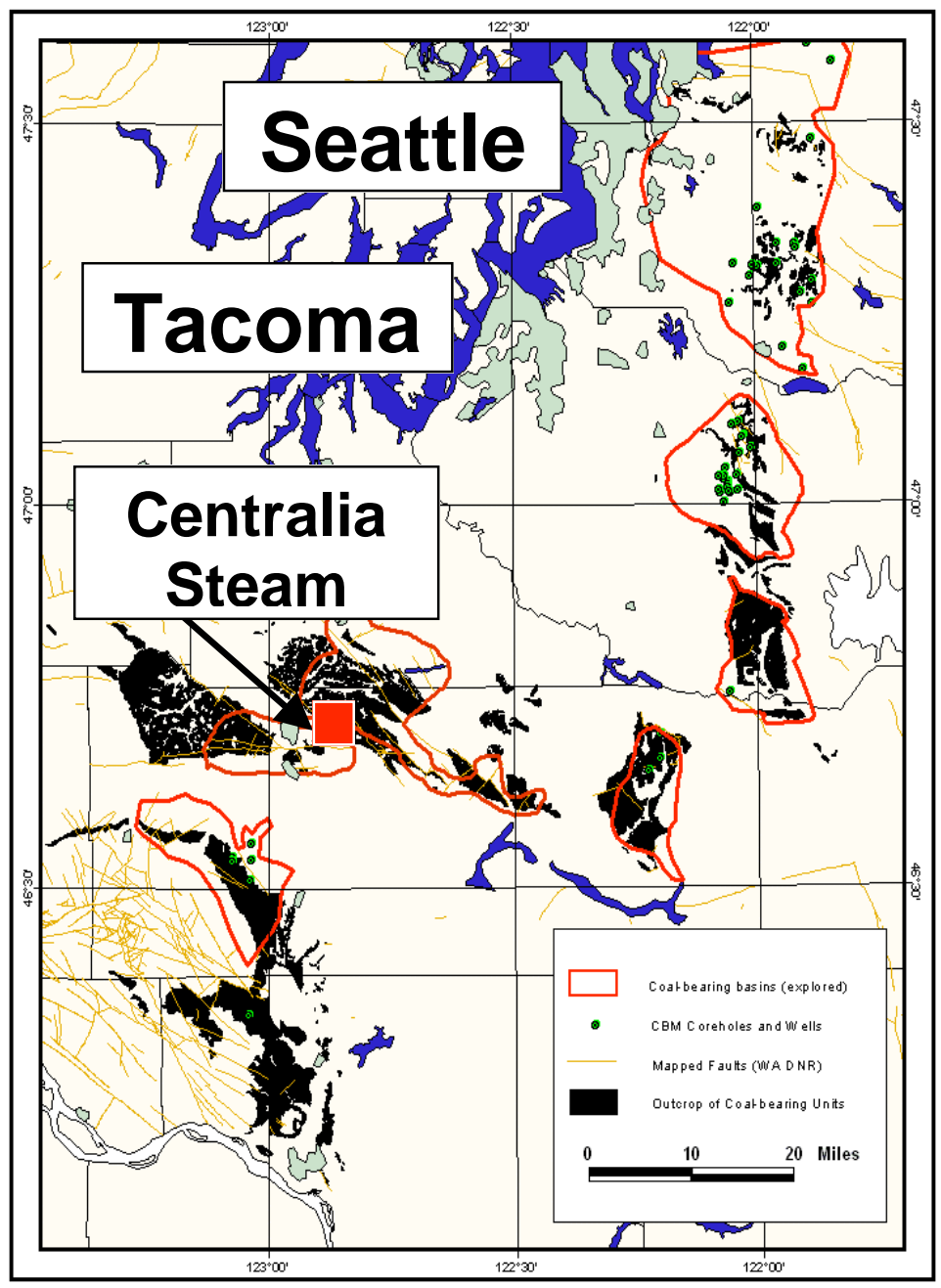

Figure 16. Estimate of extent of coal basins in Puget Trough

In Oregon, there are three main sedimentary basins in the Coastal Ranges province: Astoria-Nehalem, Tyee-Umpqua, and Coos Basins (Figure 17). They extend beneath the Willamette Lowlands, which separate the Coastal Range and the Cascade Mountains. Definition of the exact extent of each of these basins is problematic because of volcanic and sedimentary cover and tectonic deformation. 


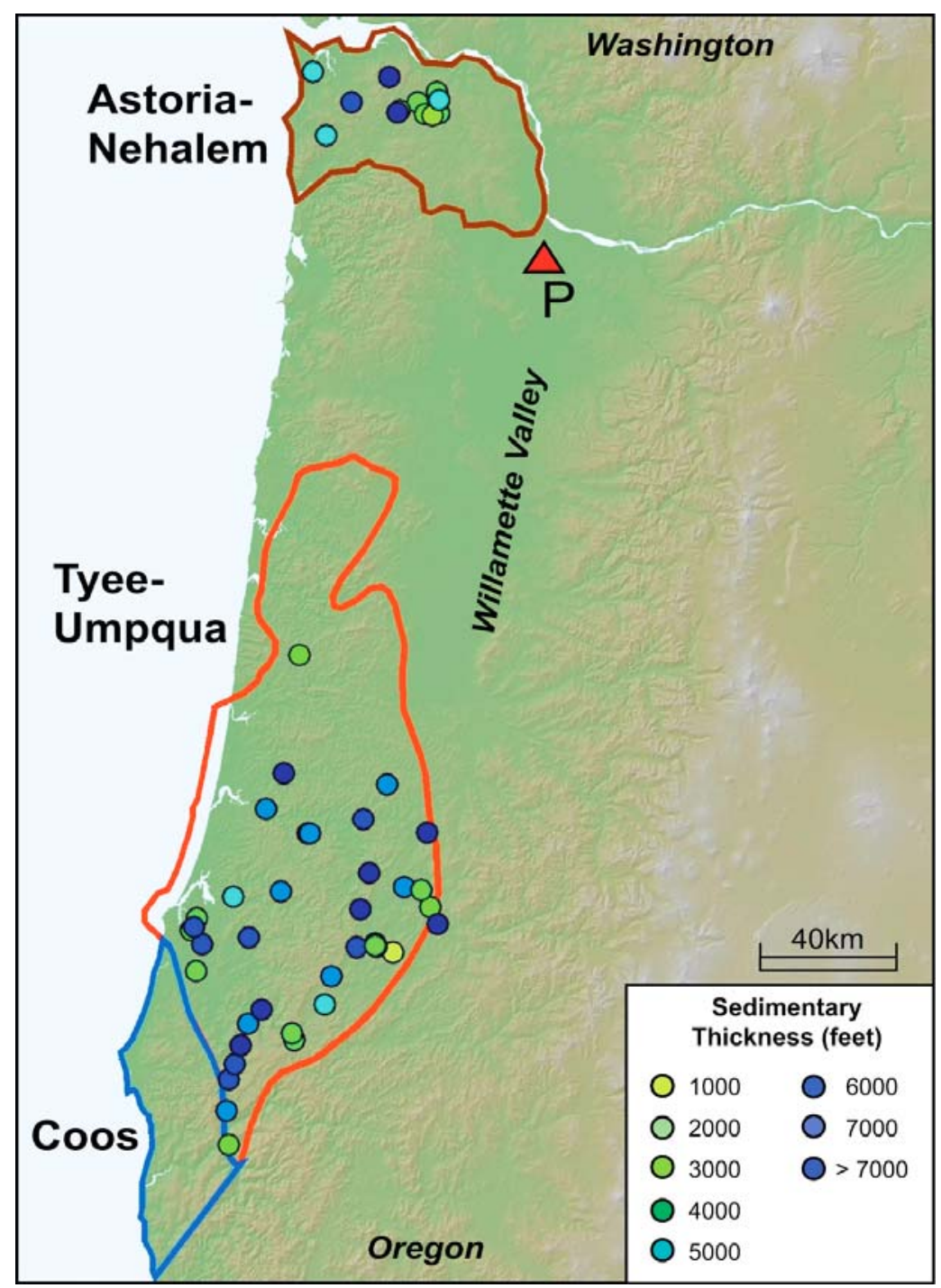

Figure 17. Sedimentary basins and sediment thickness in the Oregon Coastal Ranges. $\mathbf{P}=$ Portland, Ore.

The Tyee-Umpqua Basin occupies the southern half of the Coastal Range, extending from a latitude near Salem, beyond Roseburg, to the junction of the Coastal Range with the Klamath Mountains. To the west are the younger basinal sediments of the Coos Basin. The basin consists of more than $6,100 \mathrm{~m}(20,000 \mathrm{ft})$ of lower-middle Eocene sedimentary strata preserved in the Coastal Range hills. In fact, the basin contains two superimposed basins with different geologic trends and tectonic histories: the northeastsouthwest trending early Eocene Umpqua Basin and the north-south trending Tyee Basin.

The main geologic units identified in the basin are as follows:

- Spencer Formations-lower-mid Eocene, up to $150 \mathrm{~m}$ (500 ft) of arkosic sandstone (fluvio-deltaic). 
- Bateman Formation-mid-upper Eocene, up to $760 \mathrm{~m}(2,500 \mathrm{ft})$ of arkosic sandstone (deltaic) and mudstone.

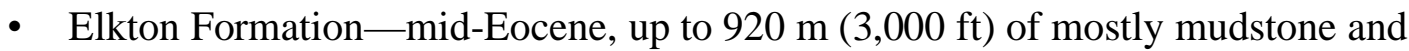
minor sandstone.

- Tyee Formation-mid-Eocene, mostly 1,830 m (6,000 ft) of sandstone, deposited in a shallow marine to non-marine deltaic environment (south) to slope and deep marine basinal margin (north). The eastern margin is truncated by younger rocks or covered by younger volcanic rocks; the western margin is a passive sill or a seamount terrane of oceanic crust. Contains several recognized members.

- Umpqua Group — upper Paleocene to lower Eocene, up to 3,050 m (10,000 ft) of mudstone, sandstone, and conglomerate (nonmarine to deep marine origin). Prominent formations recognized in reports include the Camas Valley White Tail Ridge, Tenmile, and Bushnell Rock Formations.

For the massive Tyee sandstones, porosity and permeabilities average $10.8 \%$ and $2.72 \times 10^{-15} \mathrm{~m}^{2}$ (2.76 md), respectively (Ryu and Niem, 1999).

The Coos Basin is located in coastal southwestern Oregon in the Coastal Range Province. The basin extends from the western edge of the Tyee Basin and the Klamath Mountains, and continues offshore. The geology of the basin consists of up to 3,050 m (10,000 ft) of marine sedimentary rocks. The key units are as follows:

- Bastendorff Formation-upper Eocene to lower Oligocene, up to $880 \mathrm{~m}(2,900 \mathrm{ft})$ of thinly laminated siltstone and mudstone;

- Coaledo Formation-upper Eocene, up to 1,800 m (6,000 ft) of deltaic sandstones, and prominent coal seams;

- Bateman Formation-mid-Eocene, 300 m (1,000 ft) of sandstone (near-shore, deltaic);

- Tyee Formation - similar strata to those in the Tyee Basin, up to 1,500 m (5,000 $\mathrm{ft}$ ) thick in the Coos Basin;

- Fluornoy Formation-mid-Eocene, between 300 and 1,500 m (1,000 and 5,000 ft) of sandstone and siltstone sequence;

- Looking Glass Formation-lower Eocene, basal conglomerate and overlying finegrained sandstone and siltstone sequence (up to 2,100 $\mathrm{m}-7,000 \mathrm{ft}$-thick); and

- Roseburg Formation-lower Eocene-upper Paleocene, between 3,050 and 3,700 $\mathrm{m}(10,000$ and $12,000 \mathrm{ft})$ of rhythmites and submarine basalts.

Sandstones of the Coalcedo and Fluornoy formations have porosities of $18-43 \%$ and permeabilities of $4.4 \times 10^{-15}$ to $1.8 \times 10^{-12} \mathrm{~m}^{2}$ (4.5 to $1,800 \mathrm{md}$ ). 
The Astoria-Nehalem Basin is located in northwestern Oregon, in western Columbia and eastern Clatsop counties, about 45 miles northwest of Portland. The basin contains the only economically productive gas field (known as the Mist Gas Field) in Oregon. This field occupies an area of about $13 \mathrm{~km}^{2}\left(5 \mathrm{mi}^{2}\right)$ and was first produced from in 1979. The basin geology is complex because of extensive folding and faulting. Normal and strikeslip faulting is common, with the predominant fault trend being northwest; some significant east-west and northeast-southwest faulting also exists. Faulted anticlines are reportedly the most common trap in the Mist Field. The earliest sedimentary unit is the mid-Eocene Yamhill Formation (siltstones and shales). Although the sedimentary units interfinger with the volcanics, the Yamhill does contain a prominent sandstone member. The Cowlitz Formation overlies the Yamhill Formation, and consists of micaceous, arkosic-basaltic marine sandstone, siltstone, and mudstone. Of key importance is the gasproducing Clark \& Wilson $(\mathrm{C} \& \mathrm{~W})$ sandstone, which is overlain by a thick shale unit. The $\mathrm{C} \& \mathrm{~W}$ sandstones have porosities up to $39 \%$ and permeabilities from $9.9 \times 10^{-16}$ to $1.4 \times 10^{-12} \mathrm{~m}^{2}$ ( 1 to $1,400 \mathrm{md}$ ). A sequence of marine sedimentary units overlies the Cowlitz Formation and consists of thickly to thinly bedded tuffaceous mudstone, siltstone, and sandstone. Key units include the Spencer, Keasey, Pittsburg Bluff, and Astoria Formations (all mid-upper Eocene).

There are several interior basins in Washington and Oregon that contain sedimentary deposits. Very little is known about the geology and properties of the rocks in these basins, but they could be potentially important for sequestration because of the proximity to power plants. These basins include the Methow, Chiwaukum, Ochoco, and Hornbrook. The Methow Basin contains approximately 4,000 m (13,000 ft) of sedimentary rocks, including several massive sandstones in the Winthrop Formation. The Chiwaukum Basin contains about 5,800 $\mathrm{m}(19,000 \mathrm{ft})$ of continental sedimentary sequences. The Ochoco Basin contains more than 1,500 $\mathrm{m}(5,000 \mathrm{ft})$ of fluvio-deltaic sandstones and conglomerates, and the Hornbrook Basin contains about 1,200 m (4,000 ft) of sediments. Hornbrook Formation sandstones have porosities of $6.3-18.6 \%$ and permeabilities up to $1.2 \times 10^{-15} \mathrm{~m}^{2}(1.2 \mathrm{md})$.

\subsection{Nevada}

In Nevada, ongoing crustal extension is responsible for the current basin-and-range topography. Essentially every mountain range is bounded on one or both sides by a fault that has been active in Quaternary time (Price et al., 2005). Sediments that have filled the basins between the mountains could provide sequestration targets, but there is generally a paucity of information on the structure and properties of these basin-filling sediments. Figure 18 shows the basins in which fill is greater than $1 \mathrm{~km}(0.6 \mathrm{mi})$, based on interpretation of gravity data (Price et al., 2005), with no distinction based on rock type or structure. If all potential screening criteria are applied, the basins with the largest areas of potential for $\mathrm{CO}_{2}$ sequestration by injection into saline aquifers are Granite Springs Valley in Pershing County, Antelope and Reese River Valleys in Lander County, and Ione Valley in Nye County. Each contains $30 \mathrm{~km}^{2}\left(12 \mathrm{mi}^{2}\right)$ or more area. The Nevada Bureau of Mines and Geology (NBMG) has no records of deep (>1,000 m, or >3,300 ft) wells in any of these areas (Price et al., 2005). 


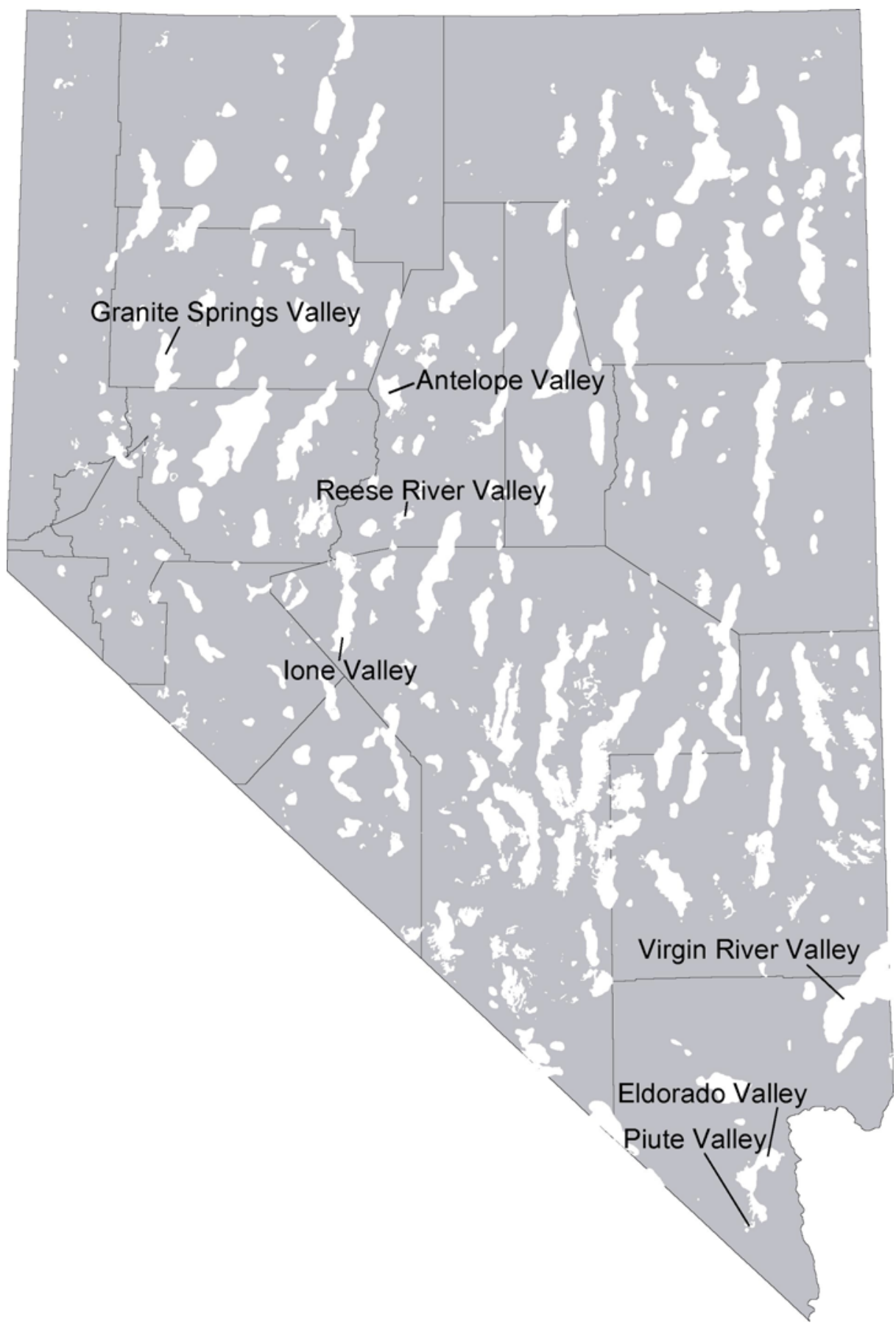

Figure 18. Nevada basins with fill thickness greater than $1 \mathrm{~km}$ (Price et al., 2005)

The NBMG constructed a conceptual model of oil and potential $\mathrm{CO}_{2}$ reservoirs and seals in Nevada (Figure 19) (Price et al., 2005). NBMG states that oil occurs in two broad types of reservoirs in Nevada: fractured and permeable Paleozoic sedimentary rocks (mostly limestones but locally also sandstones), and fractured Tertiary ash-flow tuffs. They conclude that permeable, unfractured sandstones may occur in the Paleozoic section 
and in the Tertiary valley-fill sequences in the basins. Seals for the oil reservoirs and, hence, potential $\mathrm{CO}_{2}$ sequestration sites include Paleozoic marine shales, Tertiary lacustrine shales, and the nonwelded clay- or zeolite-altered upper zones of ash-flow tuffs (Price et al., 2005). NBMG concludes that the best seals appear to be above the Paleozoic-Tertiary unconformity.

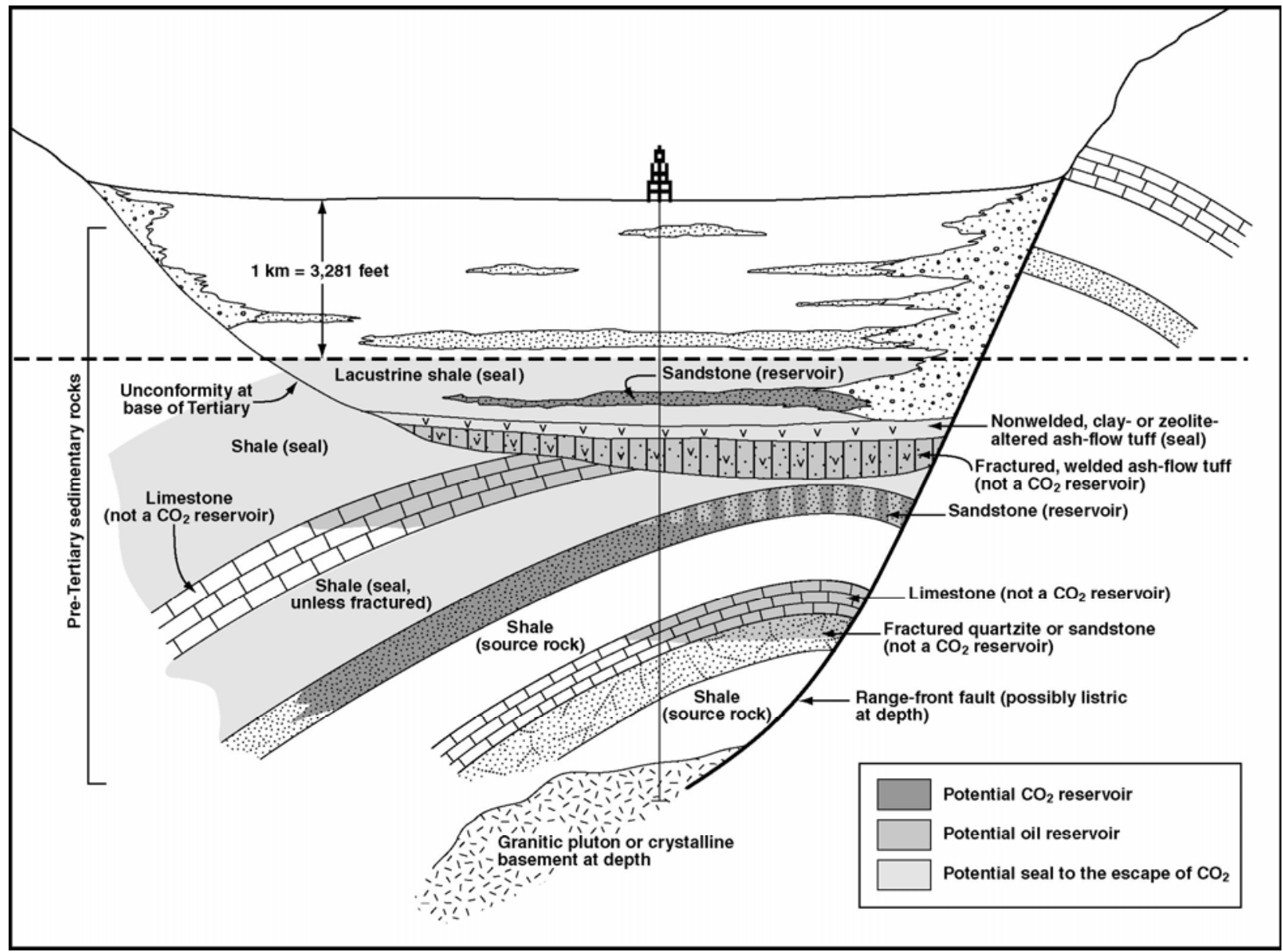

Figure 19. Conceptual model of oil reservoirs and saline formations in Nevada (Price et al., 2005) 


\section{Conclusions}

Phase I characterization of regional geological sinks shows that geologic storage opportunities exist in the WESTCARB region in each of the major technology areas: saline formations, oil and gas reservoirs, and coal beds. This characterization work focused on sedimentary basins as the initial most-promising targets for geologic sequestration. GIS layers showing sedimentary basins, and oil, gas, and coal fields in those basins, were developed. The GIS layers were attributed with information on the subsurface, including sediment thickness, presence and depth of porous and permeable sandstones, and, where available, reservoir properties. California offers outstanding sequestration opportunities because of large capacity and the potential for value-added benefits from EOR and EGR. The estimate of the storage capacity of saline formations in the ten largest basins in California ranges from about 150 to about $500 \mathrm{Gt}$ of $\mathrm{CO}_{2}$, depending on assumptions about the fraction of the formations used and the fraction of the pore volume filled with separate-phase $\mathrm{CO}_{2}$. Potential $\mathrm{CO}_{2}-\mathrm{EOR}$ storage was estimated to be $3.4 \mathrm{Gt}$, based on a screening of reservoirs using depth, an API gravity cutoff, and cumulative oil produced. The cumulative production from gas reservoirs (screened by depth) suggests a $\mathrm{CO}_{2}$ storage capacity of $1.7 \mathrm{Gt}$. In Oregon and Washington, sedimentary basins along the coast offer sequestration opportunities. Of particular interest is the Puget Trough Basin, which contains up to $1,130 \mathrm{~m}(3,700 \mathrm{ft})$ of unconsolidated sediments overlying up to 3,050 m (10,000 ft) of Tertiary sedimentary rocks. The Puget Trough Basin also contains deep coal formations, which are sequestration targets and may have potential for ECBM. More detailed characterization and further refinement of capacity estimates will be carried out in Phase II.

\section{References}

California Department of Conservation, Division of Oil and Gas (DOG), 1983, California Oil \& Gas Fields, v. 3, Northern California: California Dept. of Conservation, Division of Oil and Gas, publication TR10.

California Department of Conservation, Division of Oil, Gas, and Geothermal Resources (DOGGR), 1991, California Oil \& Gas Fields, v. 2, Southern, Central coastal, and Offshore California: California Dept. of Conservation, Division of Oil and Gas, publication TR12.

California Department of Conservation, Division of Oil, Gas, and Geothermal Resources (DOGGR), 1998, California Oil \& Gas Fields, v. 1, Central California: California Dept. of Conservation, Division of Oil and Gas, publication TR11.

Darrow, R., 1979, The Livermore basin in Geology and Engineering in the LivermoreHayward Region, California: Northern California Geological Society, field trip guidebook, $11 \mathrm{p}$.

Downey, C., and Clinkenbeard, J., 2005, An Overview of Geologic Carbon Sequestration Potential in California, report to Department of Energy, Contract No. DE-FC2603NT41984. 
Elewaut, E., Koelewijin, D., Van Der Straaten, R., Baily, H., Holoway S., Barbier, J., Lindeberg, E., Moller, H. and K. Gaida, 1996, Inventory of theoretical $\mathrm{CO}_{2}$ storage capacity of the European Union and Norway in Holloway, S. et al., The Underground Disposal of Carbon Dioxide, Final Report of Joule II project No. CT92-0031, 16-115.

Golder Associates, 2005, Sedimentary Basin Database for Washington and Oregon States for the Geologic Carbon Dioxide Sequestration Assessment, WESTCARB, report to Department of Energy, Contract No. DE-FC26-03NT41984.

Hess, R.H., 2004, Nevada Oil and Gas Well Database (NVOILWEL): Nevada Bureau of Mines and Geology Open-File report 04-1, 288 pages and dBASE file, web address: http://www.nbmg.unr.edu/lists/oil/oil.htm.

Jennings, C.W., Strand, R.G., and Rogers, T.H., 1977, Geologic map of California: California Division of Mines and Geology, scale 1:750,000.

Jones, M.A. 1999. Geologic Framework for the Puget Sound Aquifer System, Washington and British Columbia; Regional Aquifer System Analysis: U.S. Geological Survey Professional Paper 1424-C, C1-C31; 18 plates.

Kirschner, C.E., 1994, Map Showing Sedimentary Basins in Alaska, Plate 7 in Volume G-1: The Geology of Alaska, Geological Society of America, Decade of North American Geology.

Magoon, L.B. and Valin, Z.C., 1995, Sacramento Basin Province (009), in Gautier, D. L., Dolton, G.L., Takahashi, K.I., and Varnes, eds., 1995 National assessment of United States oil and gas resources - results, methodology, and supporting data: U.S. Geological Survey Digital Data Series DDS-30, Release 2, one CD-ROM.

Oldenburg, C.M., Pruess, K., and Benson, S.M. 2001, Process modeling of $\mathrm{CO}_{2}$ injection into natural gas reservoirs for carbon sequestration and enhanced gas recovery: Energy \& Fuels, 15, 293-298.

Price, J., Hess, R., Fitch, S., Faulds, J., Garside, L., Shevenell, L., and Warren, S., 2005, Preliminary Assessment of the Potential for Carbon Dioxide Sequestration in Geological Settings in Nevada, Nevada Bureau of Mines and Geology, report to Department of Energy, Contract No. DE-FC26-03NT41984.

Ryu, In-Chang, and Niem, A.R., 1999, Sandstone Diagenesis, Reservoir Potential and Sequence Stratigraphy of the Eocene Tyee Basin: J. Sed. Res., 69(2), 384-393.

Stanley, R.G., 1995a, Central Coastal Province (011), in Gautier, D. L., Dolton, G.L., Takahashi, K.I., and Varnes, eds., 1995 National assessment of United States oil and gas resources - results, methodology, and supporting data: U.S. Geological Survey Digital Data Series DDS-30, Release 2, 1 CD-ROM. 
Stanley, Richard G., 1995b, Northern Coastal province (007), in Gautier, D.L., Dolton, G.L., Takahashi, K.I., and Varnes, K.L., eds., 1995 National Assessment of United States Oil and Gas Resources-Results, Methodology, and Supporting Data: U.S. Geological Survey Digital Data Series DDS-30, 1 CD-ROM.

Tennyson, M.E., 1995, Santa Maria Basin province (012), in Gautier, D. L., Dolton, G.L., Takahashi, K.I., and Varnes, eds., 1995 National assessment of United States oil and gas resources - results, methodology, and supporting data: U.S. Geological Survey Digital Data Series DDS-30, Release 2, 1 CD-ROM.

U.S. Geological Survey National Oil and Gas Resource Assessment Team (USGS), 1995, 1995 National Assessment of United States oil and gas resources: U.S. Geological Survey Circular 1118, 20 p.

Wagner, H.C., and Batatian, L.D. 1985, Preliminary Geologic Framework Studies showing Bathymetry, Locations of Geophysical Tracklines and Exploratory Wells, Sea Floor Geology and Deeper Geologic Structures, Magnetic Contours, and Inferred Thicknesses of Tertiary Rocks on the Continental Shelf and Upper Continental Slope off Southwestern Washington between Latitudes 46N and $4730 \mathrm{~N}$ and from the Washington Coast to 125-20W: Washington Department of Natural Resources Open-File Report 85-1, 6 p. 


\section{Appendix}

\section{Category: Base Layers}

Layers:

AK_Geonames

AZ_Geonames

CA_Geonames

NV_Geonames

OR_Geonames

WA_Geonames

The Geographic Names Information System (GNIS), developed by the U.S. Geological Survey in cooperation with the U.S. Board on Geographic Names (BGN), contains information about physical and cultural geographic features in the United States and associated areas.

\section{Layer: AK_ArcticRefuge}

The coverage depicts the official legislative boundary of Arctic National Wildlife Refuge

\section{Layer: BC_Geonames}

Toponymic information is based on the Geographic Names Data Base, containing official standard names approved by the United States Board on Geographic Names and maintained by the National Geospatial-Intelligence Agency.

\section{Layer: BC_Province}

Canada Provinces represents the Canadian provinces and territories as well as coastline, international boundaries, provincial boundaries, and demographics. The boundaries are digitized from CanMap®.

\section{Layer: BC_StreamsWaterBodies}

Drainage (coastlines, rivers, lakes) in British Columbia

\section{Layer: US_Interstates}

This data set portrays the interstates in the United States.

\section{Layer: US_StatesDetailed}

U.S. state boundaries

\section{Layer: US_StatesGeneralized}

U.S. state boundaries (generalized)

\section{Layer: WC_BuiltUpAreas}

U.S. National Atlas Urbanized Areas represents urban areas in WESTCARB states derived from the urban areas layer of the Digital Chart of the World (DCW). 


\section{Layer: WC_Cities}

U.S. Cities represents locations for cities within WESTCARB states with populations of 10,000 or greater, all state capitals, and the national capital.

\section{Layer: WC_MajorRoads}

This data set portrays the major roads in WESTCARB states.

\section{Layer: WC_Railroads}

This data set includes railroads in WESTCARB states.

\section{Layer: WC_StatesDetailed}

This data set portrays the State boundaries of the contiguous states that are members of the West Coast Regional Carbon Sequestration Partnership (WESTCARB). The original data set was created by extracting the state boundary polygons from the individual 1:2,000,000-scale state boundary Digital Line Graph (DLG) files produced by the U.S. Geological Survey. These files were then merged into a single coverage.

\section{Layer: WC_StatesSimplified}

Simplified representation of the boundaries of WESTCARB states

\section{Layer: WC_StreamsWaterBodies}

The data set portrays the polygon and line water features of WESTCARB states.

\section{Category: Sedimentary Basins}

Layer: AFDA_BC:

Oil and Gas Fields for British Columbia

\section{Layer: AK_SedimentaryBasins}

This dataset consists of a polygon coverage and associated attribute data derived from the onshore and offshore portions of Kirschner (1994).

\section{Layer: AWSH_BC:}

Oil and gas well surface locations for British Columbia

\section{Layer: AZ_SedimentaryBasins}

\section{Layer: basins_bcintersect}

Layer: BC_basins

Layer: BC_Coalfields

Layer: BOGCZ_BC:

OGC Administrative Zones 


\section{Layer: CA_BasementMaster}

Layer: CA_BASINS

Principle sedimentary basins of California

\section{Layer: CA_IsopachMaster}

Layer: CA_Oil_and_Gas_Fields

Physical rock properties and production information for California oil and gas fields

\section{Layer: foothills}

Layer: NV_Valley_Fill

Areas of valley fill

\section{Layer: NV_Included_Basins}

Areas of $>=1 \mathrm{~km}$ basin fill

\section{Layer: OR_WA_Sedimentary_Basins}

\section{Layer: TPDR_NEBC:}

Petroleum development roads, British Columbia

\section{Sub-Category: Geologic Features}

\section{Layer: AK_Fault}

This digital map database represents the general distribution of major structures, lithologic contacts, faults, folds and gravity anomalies in the state of Alaska, as well as dominant movement along these faults.

\section{Layer: AK_GeologicUnits}

A regional summary of geologic formations and units that can be shown cartographically at $1: 2,500,000$.

\section{Layer: BC_Fault}

Digital file containing fault lines for British Columbia. Faults are identified by a type attribute.

\section{Layer: BC_GeologicUnits}

Polygon coverage of geology compiled at 1:100,000 scale as part of the B.C. Ministry of Energy \& Mines, Geological Survey Branch mineral potential project, 1994-1996.

\section{Layer: CA_HistoricFault}

Layer: CA_HoloceneFault 


\section{Layer: CA_LateQuaternaryFault}

Layer: CA_PreQuaternaryFault

\section{Layer: CA_QuaternaryFault}

\section{Layer: OR_500kFaults}

This theme shows all known geological faults in Oregon.

\section{Layer: OR_500kGeology}

\section{Layer: US_GeologicUnits}

This data set contains boundaries and tags for major geologic units in WESTCARB states.

\section{Layer: WA_100kFaults}

Layer: WA_500kGeology

Contacts and lithologic units for the geologic map of Washington.

\section{Layer: WA_100kGeology}

\section{Layer: WA_100kFolds}

\section{Layer: WC_QfaultL_25}

This map layer contains locations and information on faults and associated folds in WESTCARB states that are believed to be sources of significant earthquakes (those of magnitude 6 or greater) during the past 1,600,000 years.

Sub-Category: Supporting Data - Pacific Outer Continental Shelf Region (POCSR) Oil and Gas Plays

\section{Layer: POCSR_Growth_FaultPlay}

\section{Layer: POCSR_Melange_Play}

Pacific Outer Continental Shelf Region (POCSR) Play outline was digitized to represent the area encompassed by the Melange Play.

\section{Layer: POCSR_Neogene_FanSandstonePlay}

Pacific Outer Continental Shelf Region (POCSR) Play outline was digitized to represent the area encompassed by the Neogene Shelf Sandstone (conceptual) Play.

\section{Layer: POCSR_Neogene_ShelfSandstonePlay}


Layer: POCSR_Paleogene_SandstonePlay

Pacific Outer Continental Shelf Region (POCSR) Play outline was digitized to represent the area encompassed by the Growth Fault (conceptual) Play

Sub-Categorv: Supporting Data - Oregon and Washington Unconsolidated and Consolidated Basins

Layer: Puget_Sound_Quaternary

Polygons representing the thickness of the unconsolidated deposits or depth to bedrock

Basin outlines:

Layer: Alvord_Pueblo_Basin

Layer: Basin_Baker

Layer: Basin_Quincy

Layer: Basin_Umatilla

Layer: Basin_Willamette_Trough_Q

Layer: Catlow_Basin

Layer: Columbia_R_Basalt

Layer: ConsolidatedBasin_Ochoco_Basin

Layer: ConsolidatedBasin_W_Olympic

Layer: ConsolidatedBasin_Willapa_Hills

Layer: ConsolidatedBasin_Astoria_Nahalem

Layer: ConsolidatedBasin_Chiwaukum

Layer: ConsolidatedBasin_Coos

Layer: ConsolidatedBasin_Harney

Layer: ConsolidatedBasin_Methow

Layer: ConsolidatedBasin_Snake_River

Layer: ConsolidatedBasin_Swauk

Layer: ConsolidatedBasin_Tyee_Umpqua

Layer: ConsolidatedBasin_Whatcom

Layer: ConsolidatedBasinTofino_Fuca

Layer: ConsolidatedyBasin_Hornbrook

Layer: Fort_Rock_Lake

Layer: Goose_Lake_Basin

Layer: Kittitas_Basin

Layer: Klamah_Basin

Layer: La_Grande_Basin

Layer: LaPine_Subbasin

Layer: Millican_Basin

Layer: Pasco_Basin

Layer: Prineville_Basin

Layer: Puget_Sound_Consolidated

Layer: Selah_Basin

Layer: Sisters_Basin

Layer: Spokane_Basin

Layer: Summer_Lake_Basin 


\author{
Layer: Toppenish_Satus_Basin \\ Layer: Walla_Walla_Basin \\ Layer: Warner_Lakes_Basin \\ Layer: Yakima_Basin
}

\title{
Sub-Category: Supporting Data - Oregon and Washington 1995 Oil and Gas Play $\underline{\text { Assessment }}$
}

\section{Layers: \\ pr402g \\ pr452g \\ pr401g \\ pr450g \\ pr1801g \\ pr1803g \\ pr1802g \\ pr403g \\ pr405g \\ pr407g \\ pr410g \\ pr502g \\ pr404g \\ pr406g \\ pr408g \\ pr451g \\ pr501g \\ pr503g}

The fundamental geologic unit used in the 1995 National Oil and Gas Assessment (USGS, 1995) was the play, which is defined as a set of known or postulated oil and or gas accumulations sharing similar geologic, geographic, and temporal properties, such as source rock, migration pathways, timing, trapping mechanism, and hydrocarbon type. The geographic limit of each play was defined and mapped by the geologist responsible for each province. The play boundaries were defined geologically as the limits of the geologic elements that define the play, such as the limits of the reservoir rock, geologic structures, source rock, and seal lithologies.

\section{Sub-Category: Supporting Data - Oregon and Washington Isopach Maps}

\section{Layer: Alluvium_Base_Yakima}

Digital representation of the thickness of the unconsolidated sediments

\section{Layer: Base_Sub_CRBG_Geoelectric}

Digital representation of Magnetotelluric Survey Data in the Pasco area to determine the subsurface geometry of the Basalt Waste Isolation Project. 


\section{Layer: Basin_Base_Quaternary_Willamette}

Digital representation showing altitude of the bottom of the basin-fill deposits in the Willamette Lowland

\section{Layer: Basin_Base_Spokane}

Digital representation of the elevation of the base of the unconsolidated sediments

\section{Layer: Basin_Base_Umatilla}

Digital representation of altitude of top of Saddle Mountains Basalt

\section{Layer: Basin_Base_Yakima}

Digital representation of the elevation of the base of the unconsolidated sediments

\section{Layer: EdgeofCraton_Sub_CRBG}

Digital Representation of the edge of the craton

\section{Layer: Isopach_Aquifer_Willamette}

Digital representation showing thickness of the Willamette aquifer

\section{Layer: Isopach_ConfiningUnit_Willamette}

Digital representation showing thickness of the Willamette confining unit

Layer: Isopach_Consolidated_Puget

Digital representation of the isopachs of Ulatisian and Narizian surface accumulated rocks

\section{Layer: Isopach_CRBG}

Digital representation of the thickness of the Columbia River Basalt Group

\section{Layer: Isopach_CRBG_Geoelectric}

Digital representation of Magnetotelluric Survey Data in the Pasco area to determine the subsurface geometry of the Basalt Waste Isolation Project

\section{Layer: Isopach_Kittitas}

Digital representation of contours showing thickness of the overburden

\section{Layer: Isopach_Pasco}

Digital representation of contours showing thickness of the overburden

\section{Layer: Isopach_Quaternary_Puget}

Polygons representing the thickness of the unconsolidated deposits or depth to bedrock

\section{Layer: Isopach_Quincy}

Digital representation of contours showing thickness of the overburden 


\section{Layer: Isopach_Selah}

Digital representation of contours showing thickness of the overburden

\section{Layer: Isopach_Silt_Willamette}

Digital representation showing thickness of the Willamette Silt unit

\section{Layer: Isopach_Sub_CRBG}

Isopach contours for the CRBG

\section{Layer: Isopach_Sub_CRBG_Geoelectric}

Digital representation of Magnetotelluric Survey Data in the Pasco area to determine the subsurface geometry of the Basalt Waste Isolation Project

\section{Layer: Isopach_Toppenish_Satus}

Digital representation of contours showing thickness of the overburden

\section{Layer: Isopach_Ulatisian_Narizian}

Isopach of Ulatisian and Narizian surface accumulated rocks

\section{Layer: Isopach_Walla_Walla}

Digital representation of contours showing thickness of the overburden

\section{Layer: Isopach_Yakima}

Digital representation of contours showing thickness of the overburden

\section{Layer: Top_Aquifer_Willamette}

Digital representation showing altitude of the top of the Willamette aquifer

\section{Layer: Top_CRBG_Geoelectric}

Digital representation of Magnetotelluric Survey Data in the Pasco area to determine the subsurface geometry of the Basalt Waste Isolation Project

\section{Layer: Top_Sub_CRBG_Geoelectric}

Digital representation of Magnetotelluric Survey Data in the Pasco area to determine the subsurface geometry of the Basalt Waste Isolation Project

\section{Category: Sources}

\section{Layer: refineries}

Point features representing refineries in WESTCARB states

\section{Layer: CementandLimePlants}

Point features representing cement and lime plants in WESTCARB states 


\section{Layer: GasProcessingPlants}

Point features representing oil and gas processing centers in WESTCARB states

\section{Layer: PowerPlants}

Point feature class representing power plants in WESTCARB states

\section{Layer: AFCLTY_BC:}

Oil and gas facility locations for British Columbia (Oil and Gas Commission data)

\section{Rasters:}

\section{Hillshade}

Shading for cartographic purposes

\section{Elevation}

Global land 1-km base elevation 